\title{
THE INFLUENCES OF ISLAMIC ARCHITECTURE ON SIKH ARCHITECTURE IN PUNJAB REGION FROM THE $16^{\text {th }}-19^{\text {th }} \mathrm{CE}$
}

\author{
Ghada ELGEMAIEY
}

\author{
Cairo University, Egypt \\ E-mail: Ghada_elgemaiey@cu.edu.eg
}

\begin{abstract}
This paper will trace the influence of Islamic architecture on Sikh buildings in the Punjab region of the north-west of India (10th-13 ${ }^{\text {th }}$ $\mathrm{AH} / 16-19^{\text {th }} \mathrm{CE}$. This influence was a direct result of the solid roots of Islamic architecture India's Mughal Empire during the same aforementioned period. In return, the latter influenced by Islamic art and architecture in Iran.

This manuscript presents Sikh religious architecture along with its origins and components; by giving a brief overview of the Sikhism's various contexts including the region, socio-political history and analysing its architecture. It focuses on the Gurudwara; the temple and the focal point of the Sikhism.

The paper shows to what extend the Gurudwara is a distinguished example showing the combination of Mughal Indian and Safavid architecture along with Sikh entirely new units. Moreover, Hindu architecture was also one of the Gurudwara architecture origins as appear in the distribution of the units.

The study concluded that the similarity of Islamic architecture and Sikh architecture is due to that many architects and artists of the Gurudwara were Muslims.
\end{abstract}

\section{KEYWORDS}

Sikh- Punjab- India- Iran- Gurudwara- Islamic architecture.

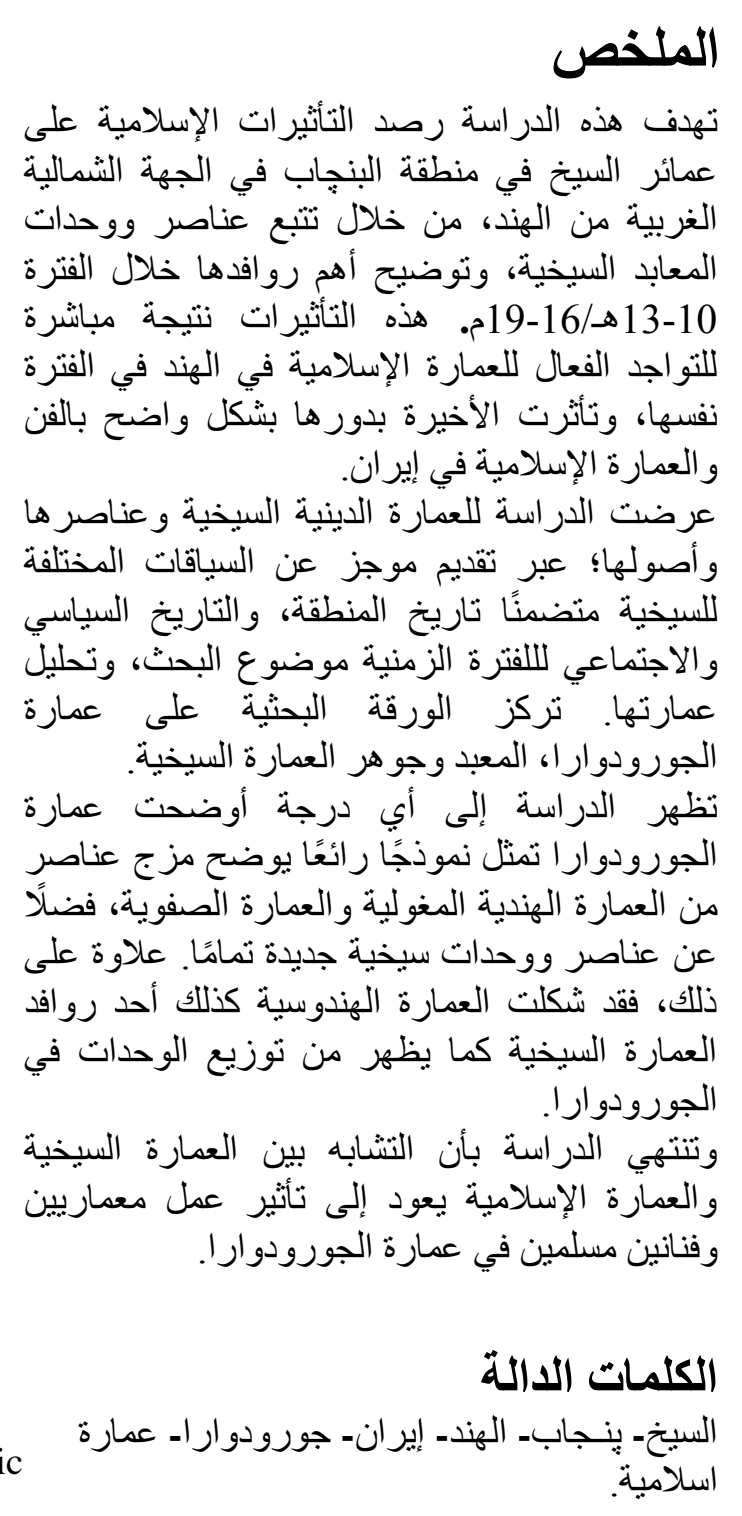




\section{INTRODUCTION}

India's religious diversity is reflected through its art and architecture. It thus makes the tracing of influences of ideas or ideologies challenging. This plethora of religion also led to a variety of religious architecture dedicated to worship. Sikhism originated around $9^{\text {th }} \mathrm{AH} / 15^{\text {th }}$ century $\mathrm{CE}$ in the Punjab region of the north-west of India before the Mughal Empire. Sikh temples were influenced by the architectural style of the period, from Hinduism, to Buddhism, Jainism, and Islamic. This research focuses on the influence of the Mughal Indian art and architecture on the Sikh one, a topic barely addressed in literature. It is examined thanks to Islamic plans, units, and motifs and their similarities with Sikh architecture and motifs, as seen in towns and temples. From 1707 CE Sikh people started to build independent cities and communities separated from the Mughal Empire. They also created a socio-political life fitting their beliefs and thoughts. This separation from Mughal Empire brought them to develop a building style also reflecting the influence of the Mughal architecture. This translation into Sikh architecture is detailed in this research.

This paper presents Sikh architecture by giving a brief overview of the region, and Sikhism as referring to its socio-political issue and its role on Sikh architecture. Some components of selected temples, their units and motifs, are introduced. Subsequently, the influence of Islamic architecture on the Sikh architecture is shown thanks to examples from Mughal and Iranian architecture.

\section{AN OVERVIEW OF PUNJAB HISTORY}

In India, the architectural style of the Punjab region ${ }^{1}$ was mostly influenced by two major factors; the Mughal Empire and Persia. The first came as a result of the domination of the Empire on India and its subcontinent, while the second was due to the fact that at the time $17^{\text {th }}-19^{\text {th }}$ centuries, Punjab looked to the north-west, towards Persia, for cultural inspiration. For Brown, "at this particular time the influence was unusually strong, as during the first half of the seventeenth century the Safavid art of Persia had attained its meridian, and the Punjab came under its irresistible spell. Not that the brick buildings in Lahore and elsewhere reproduced exactly the same style of those incomparable structure that Shah Abbas a few years earlier had set up in his new capital at Ispahan, but they were in the same tradition, and, above all, they depended largely for their appearance on the brilliant mural decoration executed in a like technique". ${ }^{2}$ Thus, the influence on Sikh architecture was mostly Iranian, due not only to the location of Punjab region and its relation with Iran, but also to the influence of Mughal architecture on the Sikh one. The Mughal style indeed merged the Iranian architecture style and the Indian one from the reign of Tahmasp.

\footnotetext{
${ }^{1}$ Punjab is the northern province of India boarding Pakistan. The name Panj-ab means the five water, because this region consist of six large rivers, the sixth not counting as it forms a boundary with the neighbouring land. Punjab is cold in winter and hot in summer, covered by farming communities, had a central forest full of wildlife that turned into a desert. This region hosted a rich civilisation from prehistory. The influences of Hinduism, Buddhism, and Islam enriched it, as well as those of India, Arab, Persia, and Turkey. Bigger, Introduction to Sikhism, 5.

In the Middle Ages, there are two Punjab, the Punjab of Mughal times during $16^{\text {th }}$ century was not the same as the Punjab of the British period in the late $19^{\text {th }}$ century. The word Punjab was given to the province of Lahore when it was enlarged by the Mughal Emperor Akbar to cover five doabs (interfluves). It was a well-defined unit, with two categories of territory: the Mughal domains and the subordinate chiefs. Grewal, Historical geography of the Punjab, 1-2.

${ }^{2}$ Brown, Indian architecture, 106.
} 
Punjab region ${ }^{1}$ was ruled by the outside since the spread of Islam in India. First, it was a part of the Delhi Sultanate, then the Mughal Empire, and then the Durrani Empire. ${ }^{2}$ From 1748-1799 AD, Punjab started to be governed locally by Misls "confederacies" (Fig. 1), which were divided in twelve sects. These were called first Jathas before being replaced with time with Misl. They played a big role in the liberation of Punjab from Mughal, Marathas, and Afghan. ${ }^{3}$ The distractions from the repeated invasions to Punjab by Ahmed Shah Abdali enabled the Sikh to revive and acquire fresh strength by lending their military services, to one party or another as occasion arose. ${ }^{4}$ From 1801 to 1849 Punjab was ruled by the Sikh Empire Maharaja Ranjit Singh ${ }^{5}$ until it became a British colony ${ }^{6}$. The ups and downs in Sikh Empire history known as transformations by the historian and archaeologist.

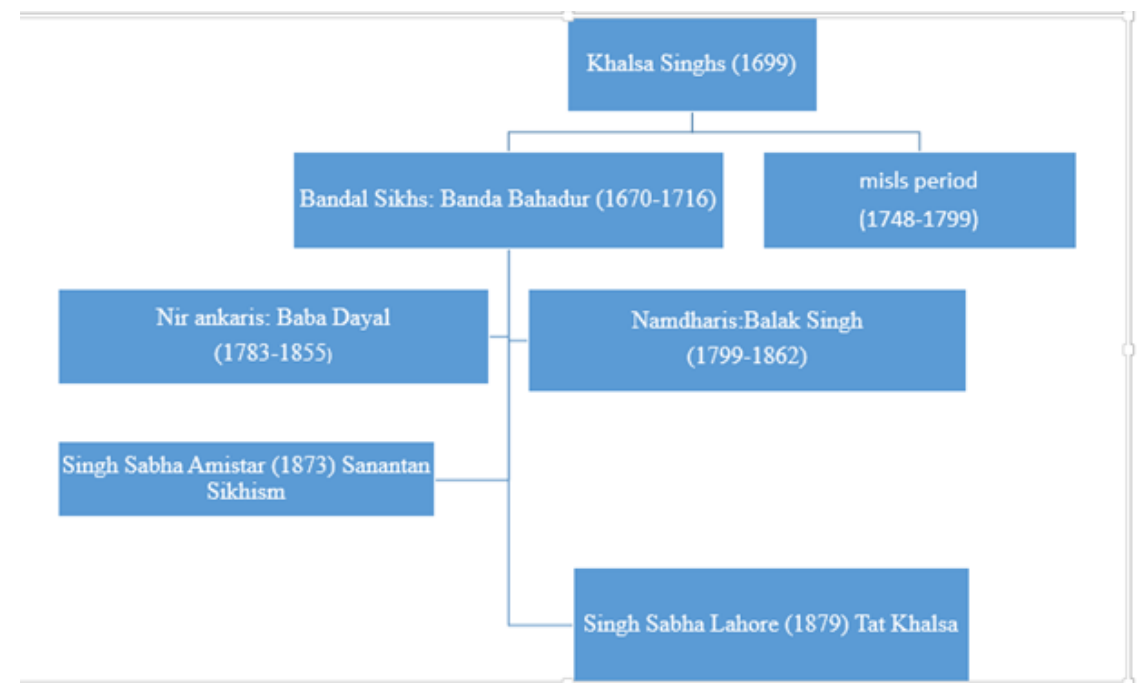

Fig. 1: Second transformation to Khalsa (baptised Sikh) from Guru "religious person" to Singh "lion, warrior" New code of conduct. (Researcher)

\footnotetext{
${ }^{1}$ In the $11^{\text {th }}$ century, the western Punjab became part of the Ghaznavid Empire, while the Rajputs held the Yamuna-Satluj Divide. During the reign of the Sultans of Delhi, the Punjab was divided into provinces, each under a Turkish or Afghan governor until it was ruled by Babur. For more than two centuries it remained a part of the Mughal Empire as the province of Lahore and parts of the province of Multan and Delhi. In the late $18^{\text {th }}$ century, the plains between the rivers Indus and Yamuna came under the Sikh rule. Maharaja Ranjit Singh united the former Mughal provinces of Lahore, Kashmir, and parts of the provinces of Multan and Kabul, while the chiefdoms of the Yamuna-Satluj Divide become subordinate to the British. In 1849, the kingdom of Lahore was wrecked, and the British province of Punjab covered nearly the entire region. Grewal, Historical geography of the Punjab, 7-8

${ }^{2}$ Durrani Empire, known as Sadozai Empire or Afghan Empire (1747-1842), was founded by Ahmed Shah Abdali (1747-1772), the son of Muhammad Zaman Khan Abdali. The Durrani Empire was established in parts of India, Punjab, Afghanistan, parts from Iran and Turkmenistan. The last Shah of the Empire is Shuja Shah Durrani (1839-1842).

${ }^{3}$ Singh, Understanding Sikh architecture, 34

${ }^{4}$ Steinbach, The Punjab, 235

${ }^{5}$ Maharaja Ranjit Singh (1780-1839), known as Sher of Punjab, was the founder of the Sikh Empire. He united the Sikh Misls and took over other local governors to establish a united Sikh empire. His period is known as a period of Sikh culture and renaissance of local Punjab art and architecture. Kapoor, "the Rise of the Sikh Empire", 466-476.

${ }^{6}$ Which started by the British East India Company, Kapoor, "the Rise of the Sikh Empire", 480-482.
} 


\title{
AN OVERVIEW OF SIKHISM RELIGION AND HISTORY
}

Sikhism ${ }^{1}$ is a mix between two religions, Hinduism and Islam. It attempted to reform Hinduism, the Bhakti movement, ${ }^{2}$ and Islam, the Sufi movement. It's said that: "Sikhism is an eclectic faith combining the teachings of Bhakti Hinduism and the Muslim Sufis". ${ }^{3}$ The main problem in Hinduism for the founders of Sikhism was dividing the community into four castes, for the benefits of Brahmin, the men of religion, and prohibited most people from their own rights, beside the Polytheism doctrine of the Hindu which is rejected by Sikhism. Their main problem with Islam was -according to their misunderstanding ${ }^{4}-$ the acts of violence.

When Islam was first introduced in India during the $8^{\text {th }}$ century, it was by Muslim traders, who spread Islam peacefully, respecting all religions and communities. However, the army invasion of Mahmud al-Ghazni (971-1030 AD) caused havoc in the minds of the local Hindu people by destroying the Hindu temples.

The founders of Sikhism: Sikhs are the followers of their ten Gurus, ${ }^{5}$ beginning with Guru Nanak and ending with Guru Gobind Singh. In 1708, after his death, personal

\begin{abstract}
${ }^{1}$ Sikhism refers to the religion as 'Sikh' or 'Singh'. Both words from Sanskrit are used in the same sense occasionally. Sikh means learner, which represents the first step of the religion authority, and Singh means Lion, which represents the second step of authority (Fig.1). Loehlin, the Sikhs and Their Scripture, 17. The origins of Sikhism came by as Sikh religious men said: "Sikhism was born out of wedlock between Hinduism and Islam after they had known each other for a period of 900 years, but once it had taken birth, it began to develop a personality of its own and in due course grew into a faith which had some semblance to Hinduism and some to Islam and yet had features that bore no resemblance to either". Singh, A History of the Sikhs, vol.1, 17. Others propose to define Sikh religion, like Majh Ki Var: "The age is like a knife. Kings are butchers. Religion has taken wings and flown. In the dark night of falsehood, I cannot see where the moon of truth is rising". Tilang said: "Modesty and religion have disappeared as falsehood reigns supreme. The Muslim Mulla and the Hindu Pandit have resigned their duties, the devil reads the marriage vows. Praises of murder are sung, and people smear themselves with blood instead of saffron". Bigger, Introduction to Sikhism, 5. Sikhism arose as a protest against the cultural and political conflicts between Hindus and Muslims. Nanak said "a humanitarian aimed at combining Hindus and Muslims into one brotherhood by a unique blend of Sufi beliefs".

${ }^{2}$ Bhakti movement was the Renaissance movement within Hinduism, which stood against casteism and polytheism. Bhakti movement started in South India and spread from the $11^{\text {th }}$ century. Ramanuja (10161137) popularised the Bhakti movement in the south of India as the best mean to salvation. He believed in the existence of one, indefinable and all-pervasive God. The main teaching of the supporters of Bhakti movement were that "God is One, God is the only reality and absolute submission to the Will of God is the only means to serve God". In Northern India, Ramanand (1360-1470), a Brahmin of North India, popularised the cult of Bhakti. But Bhakti Margo as explained by Ramanand is qualitatively different from Ramanuja. Ramanand's Bhakti Margo is emotionally oriented while Ramanuja's metaphysically oriented. Kabir, a Muslim by birth was a disciple of Ramanand. Khushwant Singh considered Kabir as "the chief Protagonist of an understanding between Hindus and Muslims". Singh, A History of the Sikhs, vol.1, p. 24. Banerjee, Guru Nanak to Guru Gobind Singh, 19-20

${ }^{3}$ Crim, Abingdon Dictionary of Living Religions, 688.

${ }^{4}$ This view is found in specific regions and times due to some accidents which reflect individual behavior, usually, for political reasons and have no reference to true Islam.

${ }^{5}$ The founding gurus of Sikhism were ten. The founder Guru Nanak (1469-1539) was born the 15th April 1469 in a village named Talwandi, in a Khatriya family of Bedi Subgroup. Nanak belonged to Bedi Subgroup, while the remaining Gurus from Ram Das onwards were Sodhis. Bingley, Sikhs, 53. He founded a village of Kartarpur on the right bank of the Ravi River, north-east Lahore and settled in it. Shaw, Sikhism. The early Sikh Panth, from Nanak until the fifth one, believed in peace and the role of speech; at the time of G. Arjan he determined to collect all the hymns of the first four gurus in a collective book and it was the first appearance of Adi Granth, the Holy book in 1604. G. Arjan was executed following the order of Jahangir, and he is considered the first martyr in Sikhism. Thus, the necessity of sociopolitical transformation happened to the Sikh (pl. 2) which led to the transformation to armed Sikhs to face the Mughal ruler and the Afghan persecution (Fig. 1). The sixth Guru G. Hargobind (1595-1644)
\end{abstract}

The Influences of Islamic Architecture on Sikh Architecture in the Punjab Region - 114 - 
guruship ended and the Sikhs revered to the Adi Granth, the Holy Book of the Sikhs. It became their own Guru $^{1}$ (Pl. 2, 3). This means that there is no Imam, Sheikh, or priest in Sikhism. ${ }^{2}$ During the time of Nanak's birth, the reigning dynasty was the Lodis. The

hunted and learnt Sikhs how to hunt and fight. He wore two swords to show the power of Sikh, one for spiritual authority (piri) and the other temporal authority (miri). Brekke, Sikh Tradition, p. 674. Those two swords are still a symbol of Sikhism. He founded Akal Takht (throne of God) opposite to the Harimandir Sahib the religious building to reflect his power. This highlighted his role being that of a Guru but a politician and a warrior. The eighth and ninth gurus were executed by Aurangzeb who destroyed Sikh schools and shrines. By the tenth, G. Gobind believed in the righteous act of picking up the arms when all other means fail, providing it is the will of God (Akal Purakh/ Sarab Loh). In addition to the code of conduct for the warrior Singhs, he created and inaugurated the Khalsa, baptized Sikh, in 1699 and named his warrior-followers Singhs. Brekke, Sikh Tradition, p. 672, 674. He proclaimed Adi Granth the new guru before he was himself assassinated. He did not include his own hymns in the Adi Granth but it was later collected by Bhai Mani Singh. Shaw, Sikhism. During the first transformation period, G. Hargobind founded two buildings; the first is Akal Takht and Lohgarh fort to defend his own people, and G. Tegh Bahadur founded Anandpur city. There was an attempt to find a new religion in North India, which has similar features of Sikhism by Baba Farid (1173-1266), Namdev (1270-1350), Ramanand (1400), Kabir (1450-1518), and Ravidas (1500). Shaw, Sikhism.

${ }^{1}$ Adi Granth, or so-called Sir Guru Granth Sahib (SGGS) collected the writings up to the ninth guru, starting from G. Nanak who created his own poetry manuscript known as Harshahai Pothi in 1530. By the time of the fifth guru, G. Arjan 1563-1606 had compiled the compositions of the first Sikh gurus as well as religious hymns from Hindu-Muslim poet-saints of different sectarian traditions in a new manuscript known as Kartarpur Pothi in 1606. At the time of the ninth guru G. Tegh Bahadur (16211675) who had been added to the main script and sealed with the Hymns of the ninth guru, this scripture known as Adi Granth was declared by the tenth guru G. Gobind 1708 the eternal Guru of the Sikh. Bekker, Sikh tradition, 675. G. Gobind did not add any of his hymns to the holy book before he released it. The Adi Granth is placed on an elevated throne in the prayer hall before the worshippers.

${ }^{2}$ Sikhism has many branches, as sons of gurus invented a new way of living and believing, mixing Sikhism and other rituals or beliefs from Hinduism or Buddhism, and some of them have many followers. The eldest son of G. Nanak, Baba Sri Chand (1494-1629), founded a doctrine called Udasi, which grew in number during the $17^{\text {th }}$ century and was respected by early Sikh Panth. Udasi has ten major orders. They believe in many Brahmanical-cum-Hindu ideas which G. Nanak and his followers did not support. There was a shift from a personal God to an impersonal reality; they respect the Gurudwara and pay attention to it at the time of conflict between Sikh Panth and government. The Udasi centres (akharas/ dhuans) were distributed in eastern India, western Punjab and Kashmir, Malwa and Doaba. Shaw, Sikhism. Another doctrine is Minas, founded by Prithi Chand (1558-1618) the eldest son of G. Arjan. It dominated controlled Amritsar the main centre of Sikhism during the $17^{\text {th }}$ century. Its followers helped the Mughal Empire against the Sikhs. The third doctrine is Masands; they represent the Guru and they become corrupt at the time of the tenth Guru. The fourth doctrine is Dhir Malias 1627. The fifth doctrine of Ram Raiyas (1646) changed words from the Adi Granth. Some of this doctrine's shrines were built during the $18^{\text {th }}$ and $19^{\text {th }}$ centuries, like Baba Dhir Mal and Dehra Dun. The doctrines of Minas, Masands, Dhir Malias, and Ram Raiyas were not acceptable by Sikh. The sixth doctrine is Nirmalas (1822); they incorporated Sikh teaching with Hindu and Vedantic. They teach ideas of Guru accepted by Sikh Panth, not the Khalsa Singhs; their centres are in Amritsar, Prayag, Ujjain, Triambak and Kurukshetra. The seventh doctrine is Bandsi Sikhs by Banda Singh Bahadur (1670-1719), as he was converted by G. Gobind and he nominated him as the leader of warrior Khalsa after his death. His followers believe that he is the eleventh Guru of Sikhism. The eighth doctrine is Akalis/ Nihangs ( $18^{\text {th }}-19^{\text {th }}$ centuries), in which they believe in three books, the Adi Granth (the holy book), The Dasam Granth (book of the tenth Guru), and the Sarob Loh Granth (book of All Steel). They are known to be fearless, skilled and resolute warriors. They were soldiers during the time of Maharaja Ranjit Singh. The ninth doctrine is Nirankaris (1783), in which they believe in living Guru after the Guru Granth Sahib. The tenth doctrine, since 1797 in North West Punjab, brought the belief in the extension of Guru Lineage. They don't consider Adi Granth as a Guru Granth. Their capital shifted to Bhaini Sahib in Ludhiana with the second leader Guru Ram Singh. The eleventh doctrine is Sanatan Singh Sabha since 1738 by Bhai Mani Singh (1673-1738) who collect Guru Gobind's work in the Dasam Granth. The First Sabha was founded in Amritsar in 1873. They founded many Sabha in Lahore. The twelfth doctrine is Tat Khalsa Singh Sabha with similar ideas as Sanatan Singh Sabha. The thirteenth doctrine is Nanaksar Movement by Nand Singh (1869/18721943). The fourteenth doctrine is Akhand Kirtani Jatha by Randhir Singh 1878-1961. The fifteenth is

- 115 - DOI: 10.21608/shedet.2021.207836 
Sultan Bahlul Lodi (1451-89), who was weak and fragile, reigned at the time. As a result, the Nanak's doctrines of Guru Nanak, the Sikh religion was propounded. Sikh people lived in peace during Akbar period. ${ }^{1}$ After his death and since the time of his son Jahangir, the non-Muslim communities faced an intolerant emperor. ${ }^{2}$ The Sikhism went through two transformational periods: the first one was since G. Nanak until the fifth Guru, at the time of G. Arjan. They named themselves as Sikh Panth, from the sixth guru till the ninth they started to assemble an army. The second one was from the time of G. Gobind, when they have been called as Sikh Khalsa ${ }^{3}$ or Sikh Singh (Pl. 1, 2, 3). Although Sikhism does not require much in the religion practice, people bear many symbols which reflect their own thoughts and beliefs, ${ }^{4}$ that especially by the time of G. Gobind, since they had many conflicts with the Mughal Empire which raised the number of martyrs. Some of those symbols are found in the Gurudwara, ${ }^{5}$ seen from distance, while others are personal items, carried by Sikh people on a daily basis, especially those who are devoted to Khalsa.

Sikh Dharma movement by Harbhajan Singh Puri in America 1971 and their tradition religion based on Kundalini yoga. Shaw, Sikhism, p.5. We can consider those doctrines or movements as a history of Sikh development, although some of these were declined by Sikh Guru themselves.

${ }^{1}$ The great Mughal emperor, Akbar the Great, kept the peace among millions of various languages and different religions. Emperor Akbar heard of Guru Amar Das, so he decided to pass through Goindwal in order to meet him. When he came to the Guru's home, he was surprised to see a large number of men and women, eating together, whereas people in India of different castes did not normally share food. The Emperor was told that eating together was the custom, and if the Emperor wished to see the Guru, he first had to sit on the ground with everyone else and share a meal! He did just that. When he eventually saw the Guru, the Emperor showed his admiration of the Langar (free kitchen). Akbar offered the Guru some local villages to provide food for the kitchen from the taxes, but the Guru refused saying "Each day's collections are spent the same day, and for tomorrow I trust in God". Bigger, Introduction to Sikhism, 4

${ }^{2}$ Since the time of Jahangir Sikh in front of the Mughal empire, the conflict started around Aurangzeb time. He started to be an enemy to Sikhs, and he executed the ninth guru in Delhi in 1675 considering him as one of the rebellious chiefs, he and all the coming leader of Sikh, which led to a battle at Chamkaur in 1704 between Aurangzeb and G. Gobind.

${ }^{3}$ Khalsa (brotherhood) Singh (lion) was started by G. Gobind Singhs, to transform sparrows into hawks, deer into lions, saints into soldiers which led to a new name "Panj Kakke" the five K'S, a new code of conduct and a new uniform. The five K's are Kesh (uncut hair), Kangha (comb), Kara (iron/steel bangle), Kirpan (sword/dagger), Kach (shorts). Shaw, Sikhism, 5

${ }^{4}$ Symbolism of the religion: most of Sikh religion aspects resemble something or somebody important, like the religious community that surrounded Nanak's has become the prototype of the Sikh community, the Guru's house the prototype for the Sikh Temple, the Gurudwara symbol of the human Guru who has been replaced by the book, the Guru Granth Sahib. Scriptures became symbolic since Guru Nanak. Guru Hargobind (1595-1644) wore two swords at the time of his succession; one representing temporal power (miri) and the other spiritual power (piri) to accompany the Harimandir Sahib's, religious and spiritual focuses. Guru Gobind invoked goddess Kali/ Durga as a powerful war legend, and to infuse a warrior's spirit in his followers for political reasons (Pl. 3). Temple, for the religion, balanced with Takht, for the political, symbolise together the coincidence of the spiritual and temporal powers. Bigger, introduction to Sikhism, 6

${ }^{5}$ Gurudwara means the "door or house of Guru". In the day of Human Guru, Gurudwara was the place for people to seek advice and guidance from their religious leader. Since the death of the tenth Guru and announcing the holy book to be the next Guru instead of a human Guru, Gurudwara houses the holy book. The holy book is treated as a human Guru. It is placed at the front of the prayer hall on a throne covered by a canopy, to dignify its presence. They use waving of Chauri which are made mostly of Yak hair. Adi Guru Granth Sahib is placed on a bed in a bedroom at night and after the evening prayers, and brought down again the next morning. Bigger, introduction to Sikhism, 3 


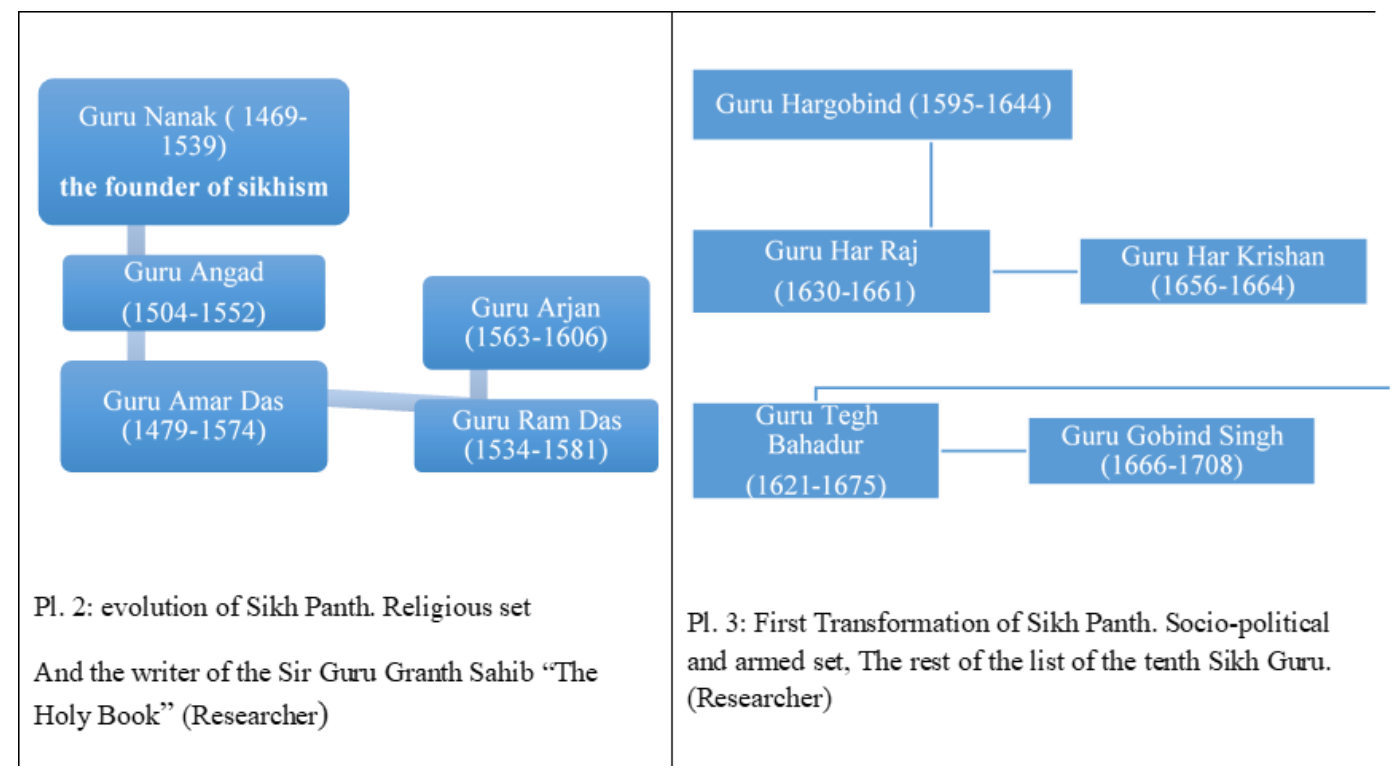

\section{SIKH ARCHITECTURE}

Sikh architecture is considered young compared to Mughal or Persian architectures. These had a direct influence on it, since the religious building of Sikh didn't require much for its performance and worship.

The influence of Persian architecture on the Sikh architecture needs to be explained further. As a result of being fugitive at the Persian court, Humayun (1531-1556 AD) brought Persian influences to the Indian architectural tradition which reformed the Mughal architecture technique and style. Sikh architecture style was the outcome of political relations between the Mughal and the Safavid so the Sikh architecture was merge of both style. In addition, the Punjab region always kept in contact with the Persian culture and art, considering itself as an extent of the Persian civilisation.

Sikh started to build new cities which reflected their own thoughts and beliefs. Cities as a main components were made in various historical sites like Kartarpur, Khadoor, Goindwal, Tarn Taran, and Amritsar (Pl. 4). Some of those cities developed to hold Takht, the seat of government. The development of the Amritsar city followed the pattern of bead and thread, where different nodes acted as the beads and the streets or linkages connecting them as the thread weaving those beads together. ${ }^{1}$ The city was planned on the basis of the topography of the city's climate and vegetation. There are regional linkages to connect new settlements with other main ones, such as Delhi and

\footnotetext{
${ }^{1}$ The Mughal cities or towns appear to be strongly centralised. In the centre, there are the citadel along with the public buildings and the main mosque surrounded by roads from all sides leading to them. It relied on colossal hydraulic works for irrigation, well-planned efficient roads, streets and lanes, and many gardens. Hasan, Mapping the Mughal city of Agra, vo. 51, p. 241. Although, there is no unified urban city plan design in the Mughal period, we can see that Fatehpur Sikri city was planned like the Mandala, a Hindu concept of architectural spatial planning and town planning. Jutla, The visual and spatial structure in Mughal urban design, 115
} 
Lahore. The city contained secular complexes, ${ }^{1}$ first the Akal Takht, then the Lohgarh fort and Bibeksar. ${ }^{2}$

\section{1- Kartapur by}

G. Nanak

\section{2- Goindval}

by G. Amar Das

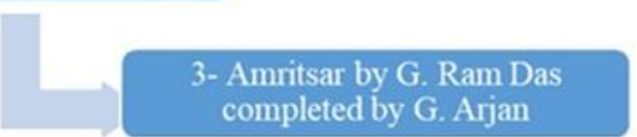

G. Arjan founded Tarn Taran and Sri Hargobindpur in Bari Doab

kartarpur in the Bist Jalandhar Doab of the Punjab

Guru Tegh Bahadur founded

the city of Anandpur

\section{Pl. 4: The headquarter cities founded by Sikh}

The temple or the shrine of Sikh is called Gurudwara which is the focal point of the Sikhism. Gurudwara's were built in the vicinity of Sikh habitations, or on sites connected to an event of one of the Gurus. The lands were often gifted to be built upon. Because Sikhs interact in political issues cause it is an emerging country, so they aimed to show their power in many aspects, like they had the capability to build impressive Gurudwara's, as some are covered by tons of gold like the Harmandar Gurudwara (the golden temple). $\mathrm{It}^{3}$ was destroyed and rebuilt many times; last time was in the $12^{\text {th }}$ $\mathrm{H} / 18^{\text {th }} \mathrm{AD}$. It remains a pilgrim site, and is a symbol of the spirit, identity, principle and beliefs of the Sikh Khalsa. ${ }^{4}$

\footnotetext{
${ }^{1}$ The slogan of Sikhism and the flag represent the secular site known as Nishan Sahib, meaning "yellow flag on a flagpole". It represents the Khalsa political and religious freedom. The flag contains the Sikh emblem, a black circle Chakkar symbolising eternity, one two-edged sword Khanda symbolising one God, and two single-edged swords in opposite directions, the Kirpans, for the spiritual and temporal powers. Bigger, introduction to Sikhism, 3

${ }^{2}$ Kumar, Critical Analysis of Jain Architecture in Bihar Region, 85-86

${ }^{3}$ Darbar Sahib (the place where the lord holds his court) or Harimandir (the house of God) or the Golden temple, as named by tourists, is the most secular place for Sikh. Since the beginning, Sikhs did not have a holy place for pilgrimage. Gurus said "God lives inside us, why search for him in a holy place," although the fifth Guru Arjan decided to build the Harimandir. The foundation stone was laid by a Muslim his name is Main Mir. According to some Sikh, Emperor Akbar offered a land to G. Amar Das's daughter and it was accepted and the town which grew up on this land became Amritsar, the city of nectar. To provide a water supply and a pool for ritual washing, the Guru's son-in-law Jetha dug a large basin. On an artificial island created in its centre, the Darbar Sahib or Golden Temple stands. Bigger, introduction to Sikhism, 4.

${ }^{4}$ Dhillon, "Gurdarshan Singh. Singh Sabha Movement-A Revival", 243-262.
} 
The predominant style of the Sikh Gurudwara was established between 1587 and 1601 $\mathrm{AD}$, after the construction of the Harmandar Sahib ${ }^{1}$ at Amritsar. The architecture of Gurudwaras may vary in form and scale. However, the basic elements of the Gurudwara's remain the same. The main unit of Gurudwara is the prayer hall, the hall of Guru Granth Sahib, which is covered with a ribbed dome and is accessible from all sides. Although there is no standard orientation to the east or west of the building. The main entrance portal is in the same axis than the prayer hall. Pilasters are important elements in Sikh architecture. ${ }^{2}$ The Gurudwara contains the main hall (Prakash) of Guru Granth Sahib and the attending room -hall- sangat, the resting room for Guru Granth Sahib, the kitchen, offices, the Sarai (the lodging facilities for pilgrims), accommodation rooms, the library. Other buildings can be added to the main shrine depending upon historical importance of the Gurudwara or on the number of visitors to a particular shrine.

Sikhism religious architecture, due to its mixed heritage of Hindu and Islam, includes aspects from Hindu temples. ${ }^{3}$ This is seen in Adi Granth, in the presence of idols, especially at the time of conflict with the Mughal Empire to show and maintain the different between themselves and Muslims. European influence also made its way to the Mughal court at the time of Shah Jahan (1627-1658), but it was confined to the minor and applied arts only, ${ }^{4}$ thus having no direct impact on the Mughal architecture.

\section{ARCHITECTURAL PLAN}

Sikh Gurudwara's in Punjab show four different plans $^{5}$ (Pl. 5), mostly following similar plan. The four categories are:

$\mathbf{1}^{\circ}$ Square Plan (PI. 5): The oldest plan of Gurudwara / Sahib is the square one, divided into three different design. The first design is plain square form represented by a good example is the Gurudwara Darbar Sahib at Tarn Taran (1590-1597). It consists of three stories, the basement having arcades. The ground floor and first floor consist of an

\footnotetext{
${ }^{1}$ Two major features in the Golden Temple set it apart from Hindu temples and Islamic Mosques. It was built on a lower plinth than its surrounding area, so the visitors have to go down steps in order to pay homage to the holy shrine. This comes from the idea that God could be reached by bending low. The other distinguishing feature was that it was made open on all four sides unlike Hindu temples which were closed on three sides. The four sides imply open entry to all. Singh, Aotearoa Sikh Architecture, 41-42. Many mosques in India and other Islamic countries have this feature of four open sides porches or open entrances which lead to the centre.

${ }^{2}$ Bhui, the Golden Temple, 17

${ }^{3}$ Hindu temples did not follow fixed plans, varying according to climate and geography. Plans of the temples rely on the quantity of parts that existed inside the temple, and the mandala. Every aspect of the temple units has its symbolic. The Yoga Tattva Upanishad talks about symbolism as the five essential components that constitute the material premise of the whole universe. Earth components are spoken to by 'a 'square', water with a 'semi-hover', fire by a 'triangle', air by a 'six-calculated figure' and ether (sky) by a circle. The point without measurement dab (bindu) is the concentration of all vitality. The symbol in the sanctum possesses the focal position and the temple speaks to the next essential structures. The architectural elements of a sophisticated temple mirror this key symbolic. The over five structures are addressed in a mandala known as Vishva-Karma mandala, which is viewed as essential to all temple architecture. The four sides of the mandala symbolise the four directions and the edges of the square to the four mid-directions; each of the eight quarters is managed by a god. The internal circle symbolises the 'Creator' (Brahma), which is emblematic of movement, monitored by eight directions. The mandala is emblematic of the whole universe. The 'all producer' (Creator) is also the ancestor. The entire mass of scripture, comprising of manuals of architecture, figures, and paintings, is known as Agama. Early temples were presumed to be worked by this All-creator. Kumar, Jain architecture, 45

${ }^{4}$ Brown, Indian architecture, 105

${ }^{5}$ This is the survey at the time of this study.
} 
external square and an internal one; the internal one is covered by a dome. Between the external and internal squares, a passage is circumnavigating around the prayer hall Parkash Asthan (Figs. 1, 2). The Gurudwara is on the eastern side of the holy tank, with 22 steps descending to the water from all sides. ${ }^{1}$

In Gurudwara Baba Bir Singh (Amritsar, early $17^{\text {th }}$ century), the simple plain structure consists of one square floor, covered by a dome, with four entrances. In the Gurudwara terrace there are ten columns, one on the eastern side, two on the northern, three on the southern, and four on the western. Those columns and its distributions symbolise the ten Guru and their roles' plan in Sikhism. The Gurudwara Sisganj Sahib (Anandpur, late $17^{\text {th }}$ century) consists of two square floors, external and internal squares on both floors, with a circumnavigating passage around the prayer hall.

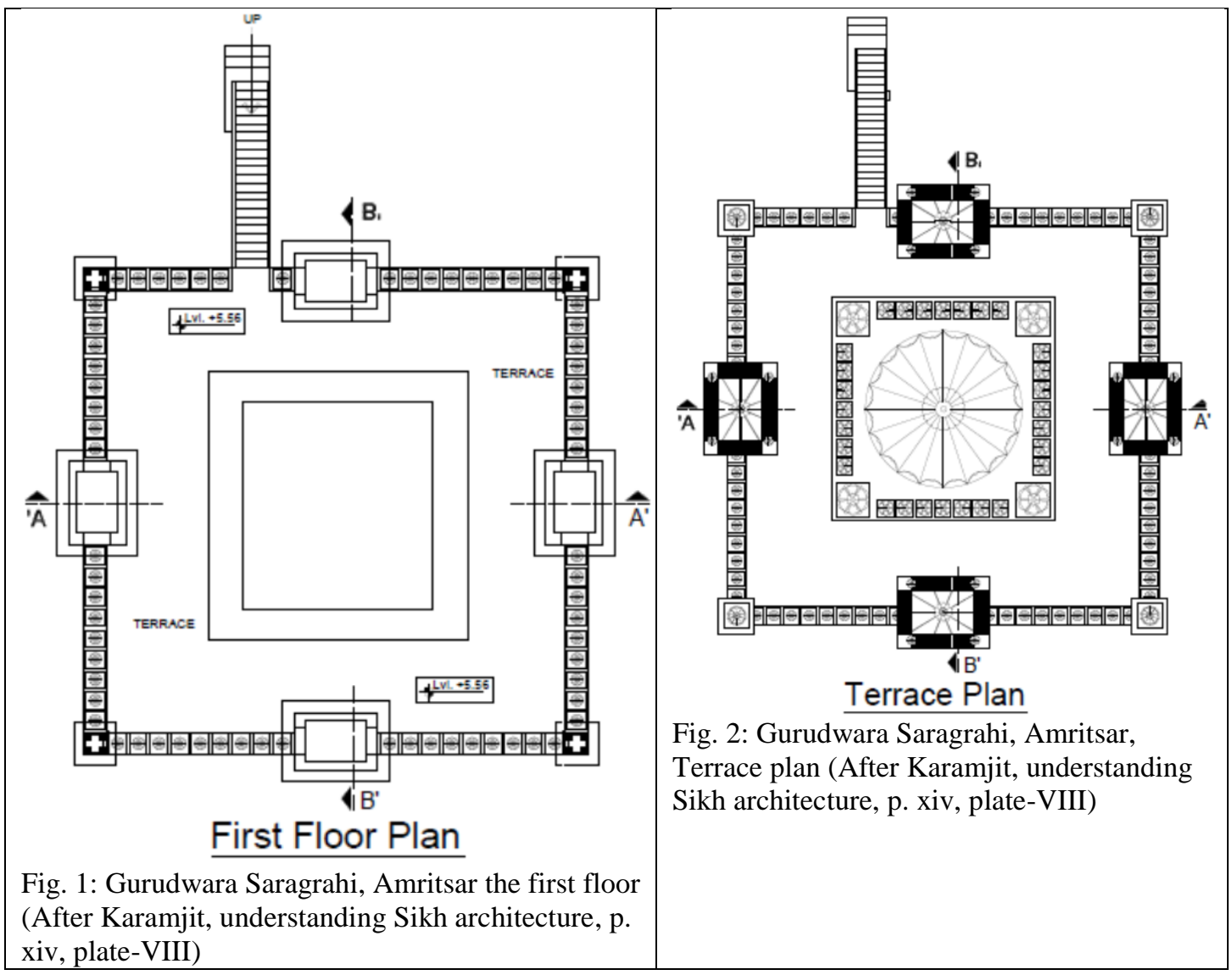

The parapet of the first floor is crowned with square kiosks on all four corners and 15 small cupolas in between. ${ }^{2}$ Gurudwara Burj Sahib (Dhariwal, mid- $18^{\text {th }}$ century) consists of two squares floors, every floor has four crusader pillars, which form a prayer hall with passage around, covered by a dome. In Gurudwara Pipli Sahib (Amritsar, N.D) consist of three square stories (Fig. 3), with four crusader pillars creating a circumnavigating passage. Gurudwara Chola Sahib (Dera Baba Nanak, 1830) (Fig. 4, 5) has one single square floor with an octagonal dome in the centre. Regarding Gurudwara Achal Sahib (Batala, late $19^{\text {th }}$ century), its three floors square structure

\footnotetext{
${ }^{1}$ Singh, "Sikh architecture", vol.4, 100.

${ }^{2}$ Singh, "Sikh architecture", vol.4, 135.
} 
consists of internal and external squares, four crusader pillars, and the prayer hall being covered by a dome.

Fig. 3: Gurudwara Pipli Sahib,
Amritsar,
$\begin{aligned} & \text { First floor. (After Karamjit, } \\ & \text { understanding Sikh architecture, } p .\end{aligned}$
xiv, plate- XIV)

the second design is square with rectangular or octagonal towers, towers often used as staircases, or room for akand path. The towers are topped by small domes similar to the central one. A good example of this form is the Gurudwara Fatehgarh Sahib (1711). It consists of three square floors; every floor consists of two internal squares with rectangular and L-shaped pillars; many arches are in between, with two circumnavigating passage around the prayer hall. Every corner of the Gurudwara consists of square towers covered by a ribbed dome. This Gurudwara is characterised by having a veranda (Fig. 6, 7). The Gurudwara Katalgarh Sahib (Chamkaur Sahib, 1831) consists in four square floors, with octagonal towers in every corner, two circumnavigating passages, and memorial portico entrance on the west. The main building, called Mariji Sahib, is an elegant three stories vaulted structure that stands on a high base. The large space contains an eight-metre square sanctuary. ${ }^{1}$ The Gurudwara Garhi Sahib (Chamkaur Sahib, early $19^{\text {th }}$ century) has three square floors, with four octagonal towers in every corner. The squares are divided into three equal arcades, and the middle one contains the prayer hall, topped by an onion dome. This is similar to the Gurudwara Battha and the Fatehgarh Sahib (Fig. 6, 7).

\footnotetext{
${ }^{1}$ Kumar, Critical Analysis of Jain Architecture, 88.
} 


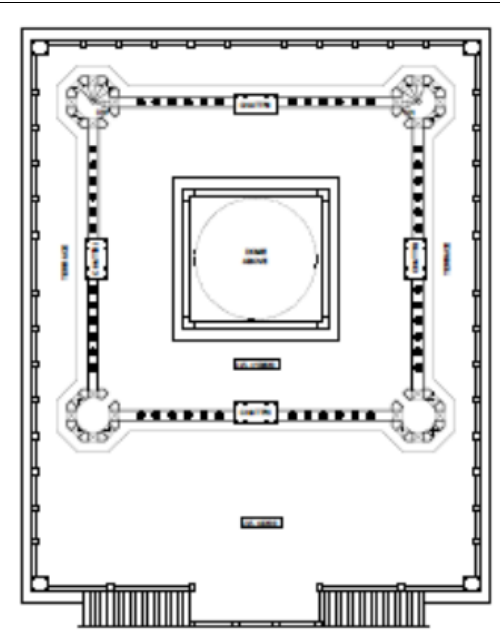

$\underline{\text { Third Floor Plan }}$

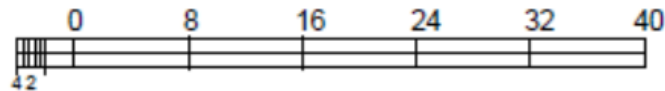

Fig. 6: Gurudwara Battha Village Kotla Nihang, Dist. Ropar, Third floor plan (Karamjit, understanding Sikh architecture, p. xiv, pl. IX-A)

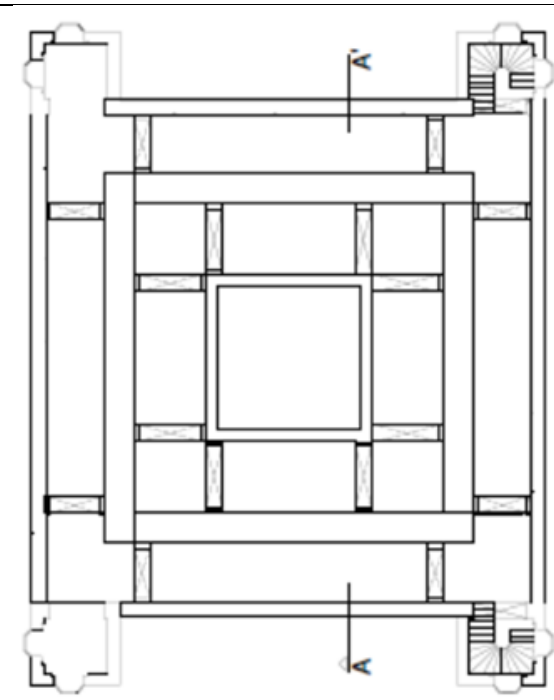

First Floor Plan

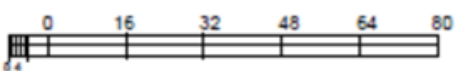

Fig. 7: Gurudwara Fatehgarh Sahib, Fatehgarh, First floor plan (Karamjit, understanding Sikh architecture, p. xiv, pl. XXIII)

The third design is square with a distinct entrance. For example, the Gurudwara Anandgarh Sahib (Anandpur Sahib, 1689) has two square floors, with one circumnavigating passage, formed by four carved pillars, topped by a ribbed onion dome in the centre, and a pavilion topping the rectangular entrance (Fig. 8, 9).

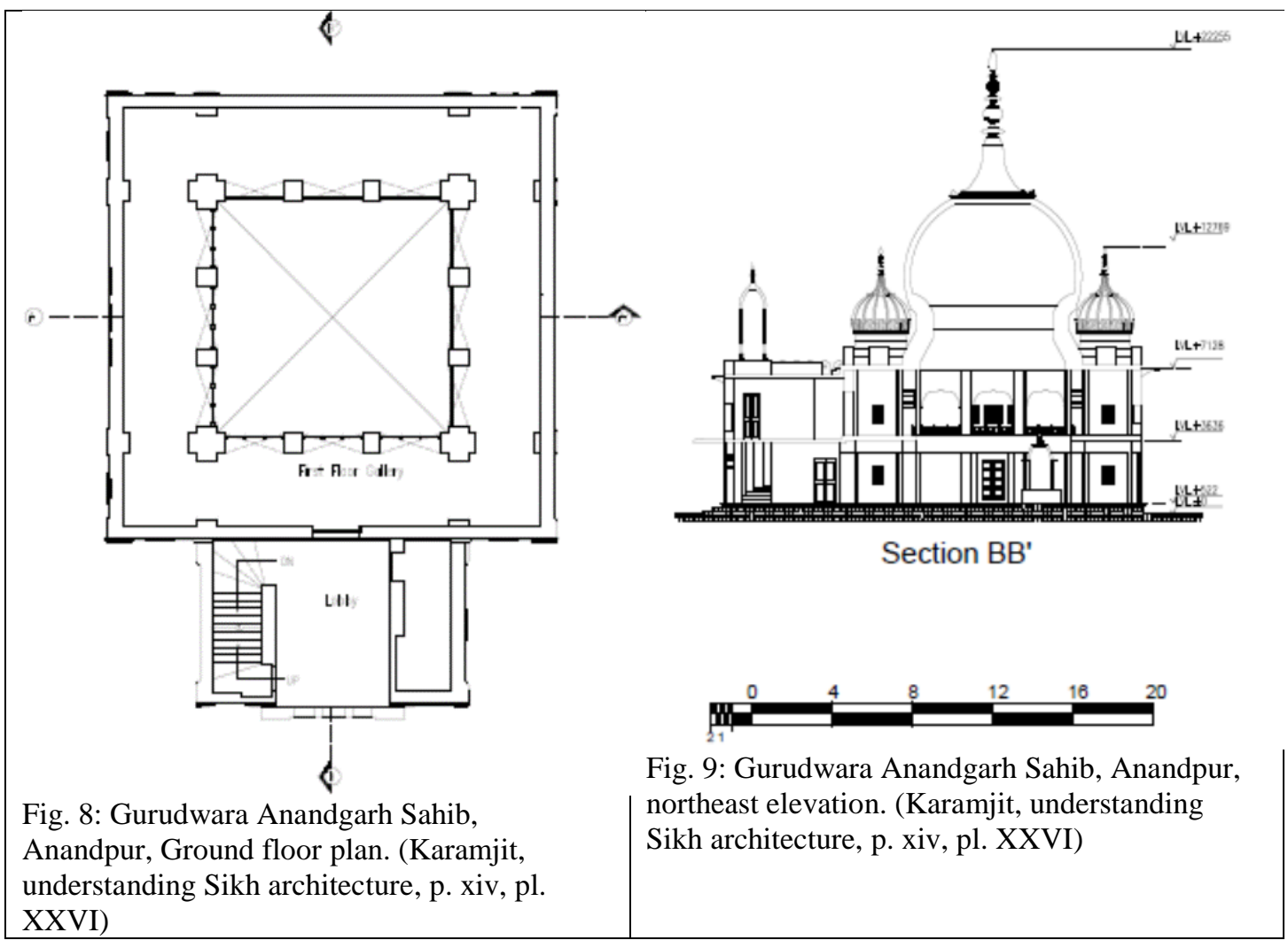

The Influences of Islamic Architecture on Sikh Architecture in the Punjab Region - 122 


\section{$2^{\circ}$ Second Plan: Rectangular Plan (PI. 5)}

This rectangular plan sahib is divided into four types: the first design is a plain rectangle. Examples are Gurudwara Bibeksar Sahib (Amritsar, 1622) with its three stories rectangular structure, located on a holy tank, the Gurudwara Datansar Sahib (Muktsar, N.D), with a rectangular floor, divided in two squares, the second one topped by a dome. Other examples are the Gurudwara Thara Sahib (Khadoor Sahib, $17^{\text {th }}$ century), the Gurudwara Shaheedan Sahib ( $19^{\text {th }}$ century), and the Gurudwara Cheharta Sahib (Amritsar, $17^{\text {th }}$ century).

The second type is rectangular design with octagonal towers in every corner. This is represented by Gurudwara Hatt Sahib (Sultanpur Lodhi, N.D, Fig. 10), which consists in four floors, surrounded by polygons supported by mini towers. The main structure has four octagonal towers, and in the last third of the rectangle stands the prayer hall topped by a height dome. Another example is Gurudwara Fatehgarh Sahib (Anandpur Sahib, $17^{\text {th }}$ century) which consists of two rectangular floors, with internal and external rectangles in every floor. In the last third of the rectangle there is the square prayer hall topped by a dome.

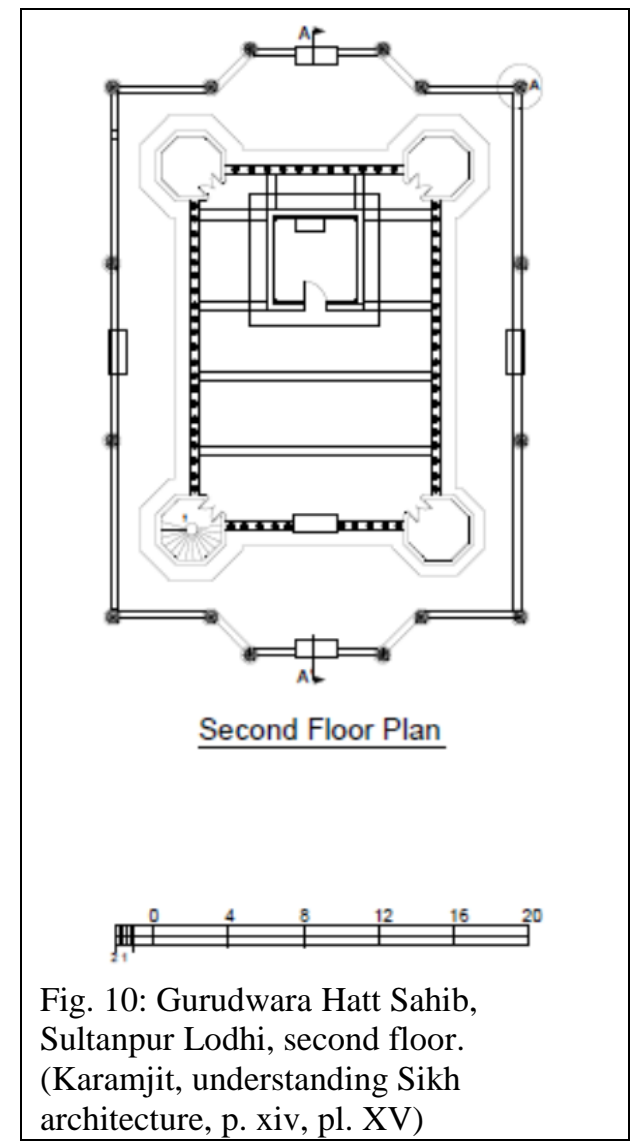

The third type is rectangular with two towers. For instance, the Gurudwara Keshgarh Sahib (Anandpur Sahib, 1689-1699) consists of four floors, with two semi-octagonal towers, a square prayer hall in the last third of the rectangle. In every corner, there are square rooms topped by a dome (Fig. 11,12). The Guru Granth Sahib is kept under a canopy outside the sanctuary, on which stands a fluted lotus dome surmounted by a high ornamental pinnacle of golden metal, and a golden Khanda. On the ceiling, the 
corners of the room and the balcony are adorned with vaulted kiosks. ${ }^{1}$ The Gurudwara Manji Sahib (Alamgir, 17 $7^{\text {th }}$ century) is five stories high, rectangular with a memorial entrance and two octagonal towers. The square prayer hall in the last third of the structure is topped by a high dome.

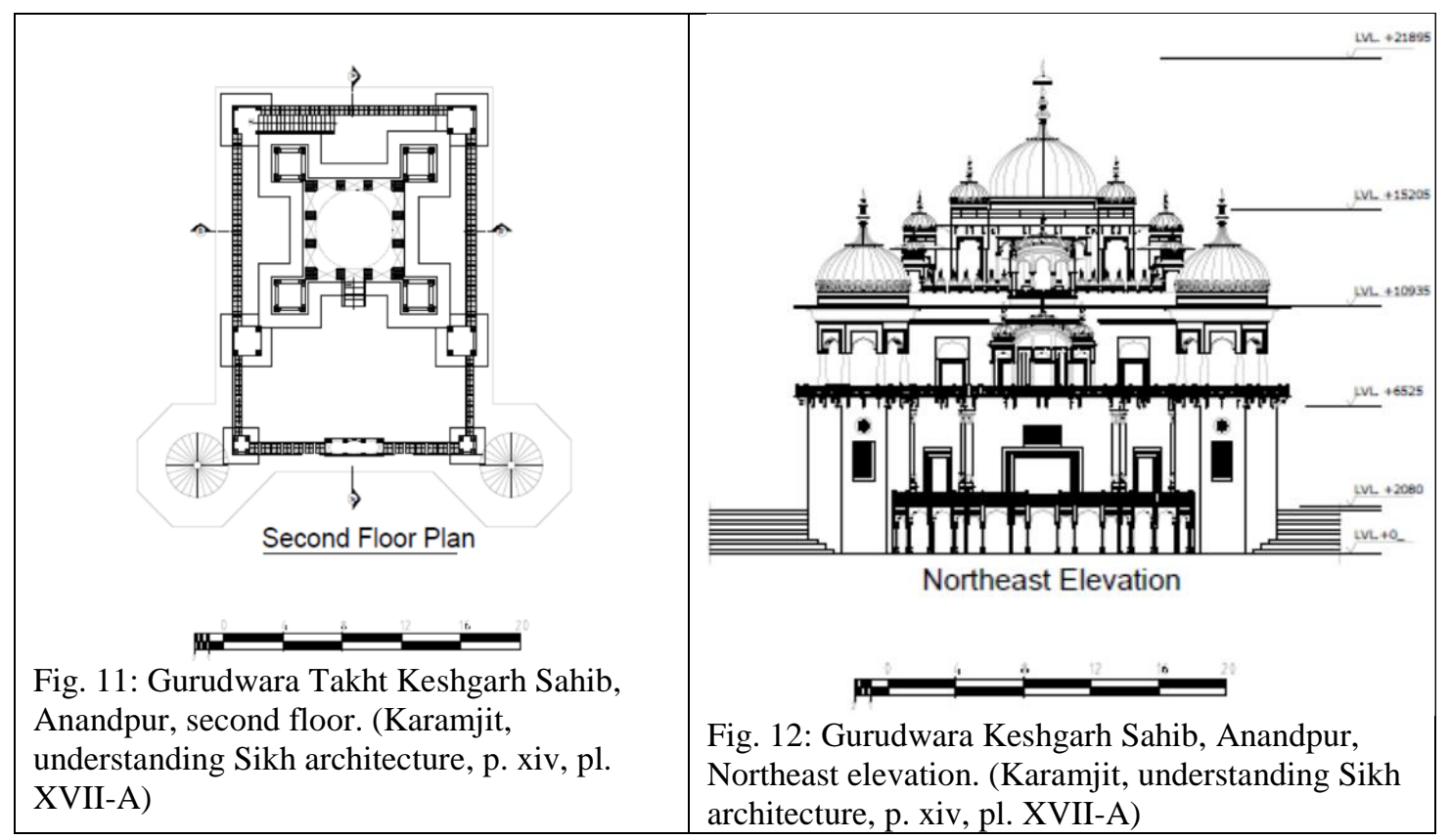

The fourth type is consist of rectangular design with a memorial entrance. For example Darbar Sahib (Dera Baba Nanak, 1719) (Fig. 13) has three stories with a memorable portal entrance, divided into three sections. The second one in the middle topped by a height dome contains the holy book. The Gurudwara Janam Asthan Patsahi Chhevin (Vadali, Amritsar, 1715) has five stories with a pillared portico entrance. In the last third of the plan, there is the square prayer hall. Gurudwara San Sahib (Amritsar, 1854) has three floors with a memorial entrance, and at the centre of the rectangular structure, there is the square prayer hall (Fig.14).

\footnotetext{
${ }^{1}$ Kumar, Critical Analysis of Jain Architecture, 85.
} 


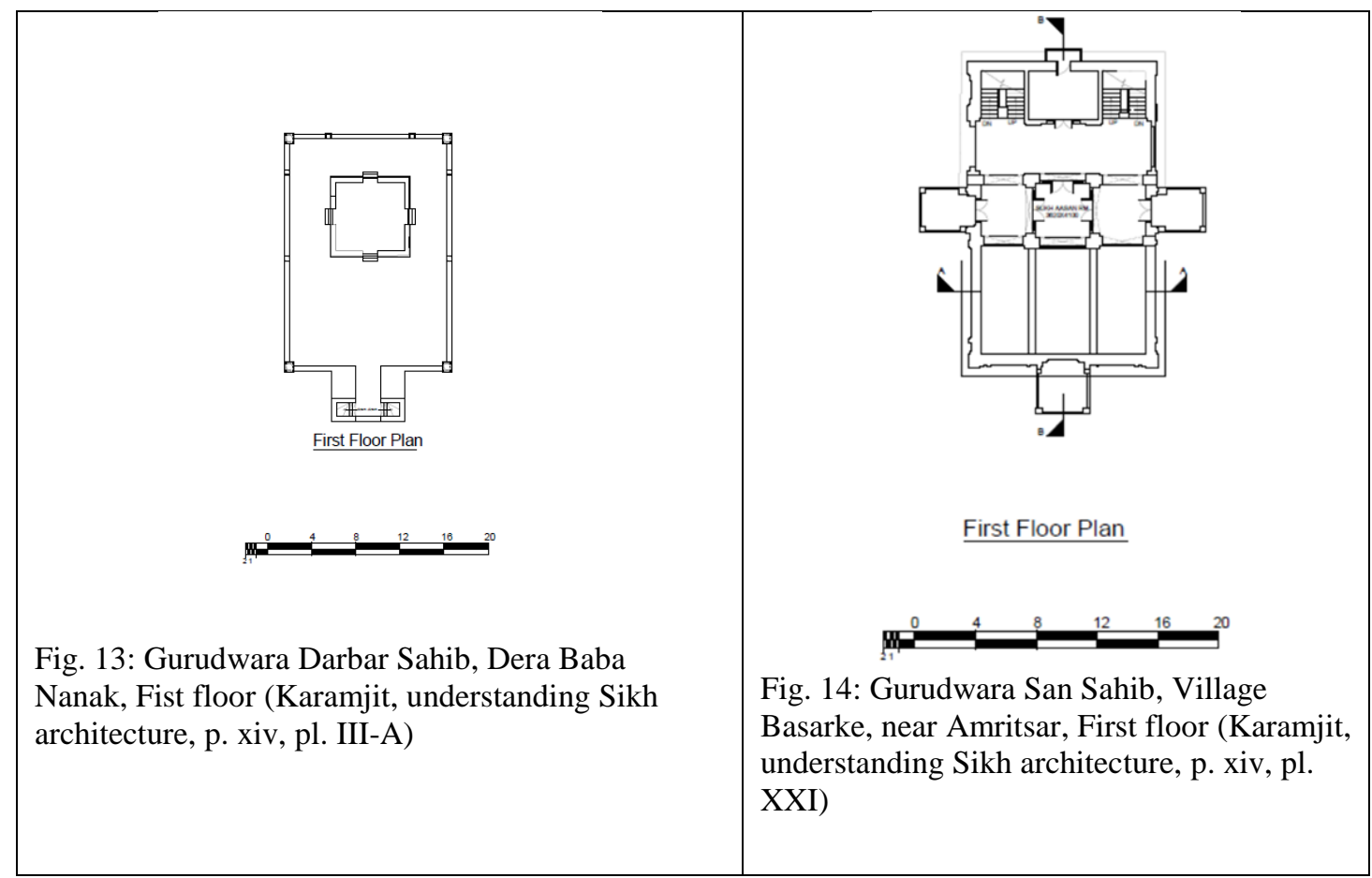

$3^{\circ}$ Third Plan: Polygonal Plan (PI. 5): Harmandar Sahib (Amritsar, 1588-1601) is considered to be the pilgrim place for Sikh. It has an hexagonal plan and consists of three floors, located on a holy tank. It is divided in two sections, the north-eastern one being the prayer hall with circumnavigating passage, and the second one arranged in three square rooms, with an added one in a different alignment and a terrace (Fig. 15, 16). Gurudwara Shaheedan Sahib (Amritsar, 1803-1823) is a hexagonal structure with two floors. In the middle of the building there is the prayer hall which is octagonal in plan, topped by a dome (Fig. 17).

One of the formal forms of the polygonal plan have been constructed in an octagonal shape, divided by two styles. The first style consists of three octagons; two internal and one external. For example, Akal Takht Sahib (Amritsar, $17^{\text {th }}$ century), Lohgarh Sahib (17 ${ }^{\text {th }}$ century), Baba Atal (Amritsar, 1778) with seven floors (Fig. 18, 19). The second style consists of two external octagons and an internal square, such as Thara Sahib (Amritsar, 17 ${ }^{\text {th }}$ century) ( Fig. 20) and Holgarh Sahib (Anandpur Sahib, $17^{\text {th }}$ century). 


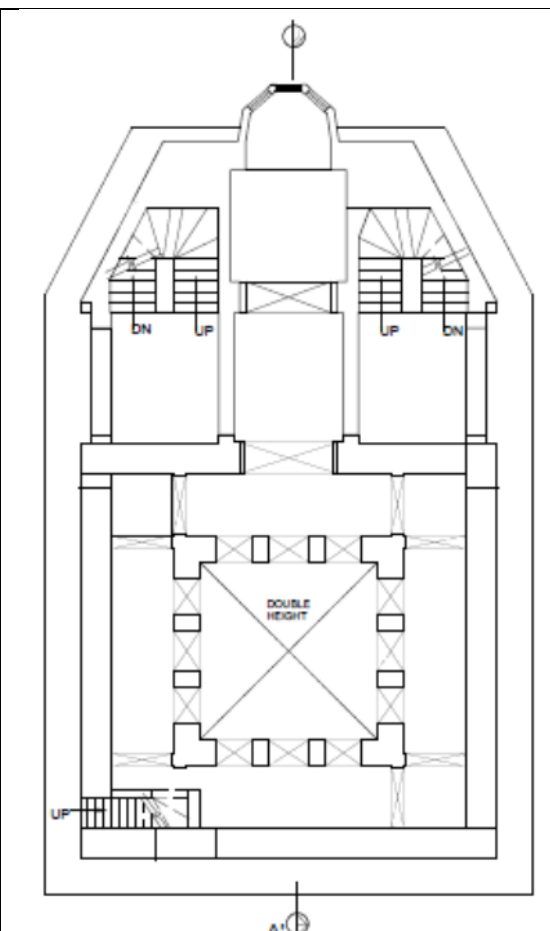

Fig. 15: Harmandar Sahib, the golden temple complex, Amritsar, Ground floor. (Karamjit, understanding Sikh architecture, p. xiv, pl. I-A)

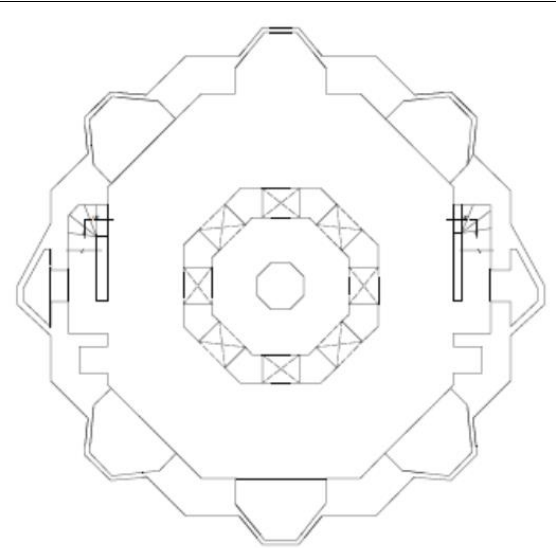

Fig. 18: Baba Atal, Amritsar. Third floor. (Karamjit, understanding Sikh architecture, p. xiv, pl. VII)

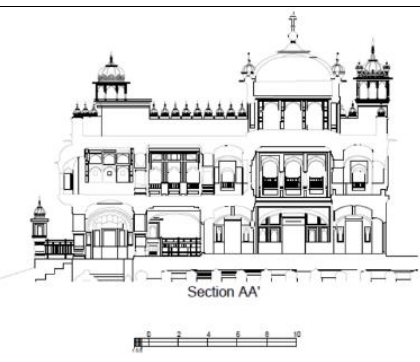

Fig. 16: Harmandar Sahib, the golden temple complex, Amritsar, Ground floor. (Karamjit, understanding Sikh architecture, p. xiv, pl. I-B)

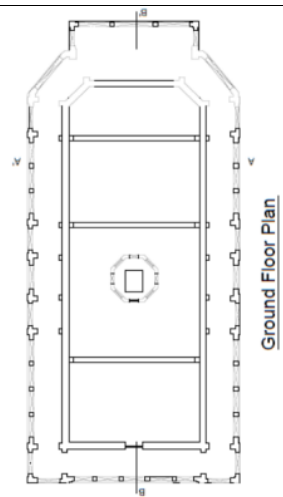

Fig. 17: Shaheedan Sahib, Amritsar, Ground floor. (Karamjit, understanding Sikh architecture, p. xiv, pl. XIII)
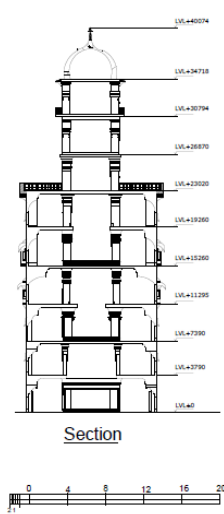

Fig. 19: Baba Atal, Amritsar. Vertical section. (Karamjit, understanding Sikh architecture, p. xiv, pl. VII)

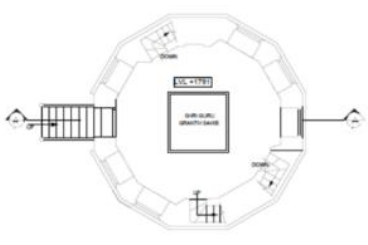

Upper Ground Floor Plan

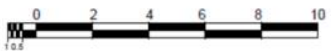

Fig. 20: Thara Sahib,

Amritsar

Ground floor. (Karamjit, understanding Sikh architecture, p. xiv, pl. XI)

$4^{\circ}$ Fourth Plan: Cruciform Plan (PI. 5): The cruciform plan is composed of apses and aisles, a western portal, and a side entrance. Gurudwara Bir Baba Buddha (near Amritsar, $17^{\text {th }}$ century) has three stories, a pillared portico, and a square prayer hall in the centre of the aisles (Fig. 21, 22). Ber Sahib (Fig. 23) is another example. 

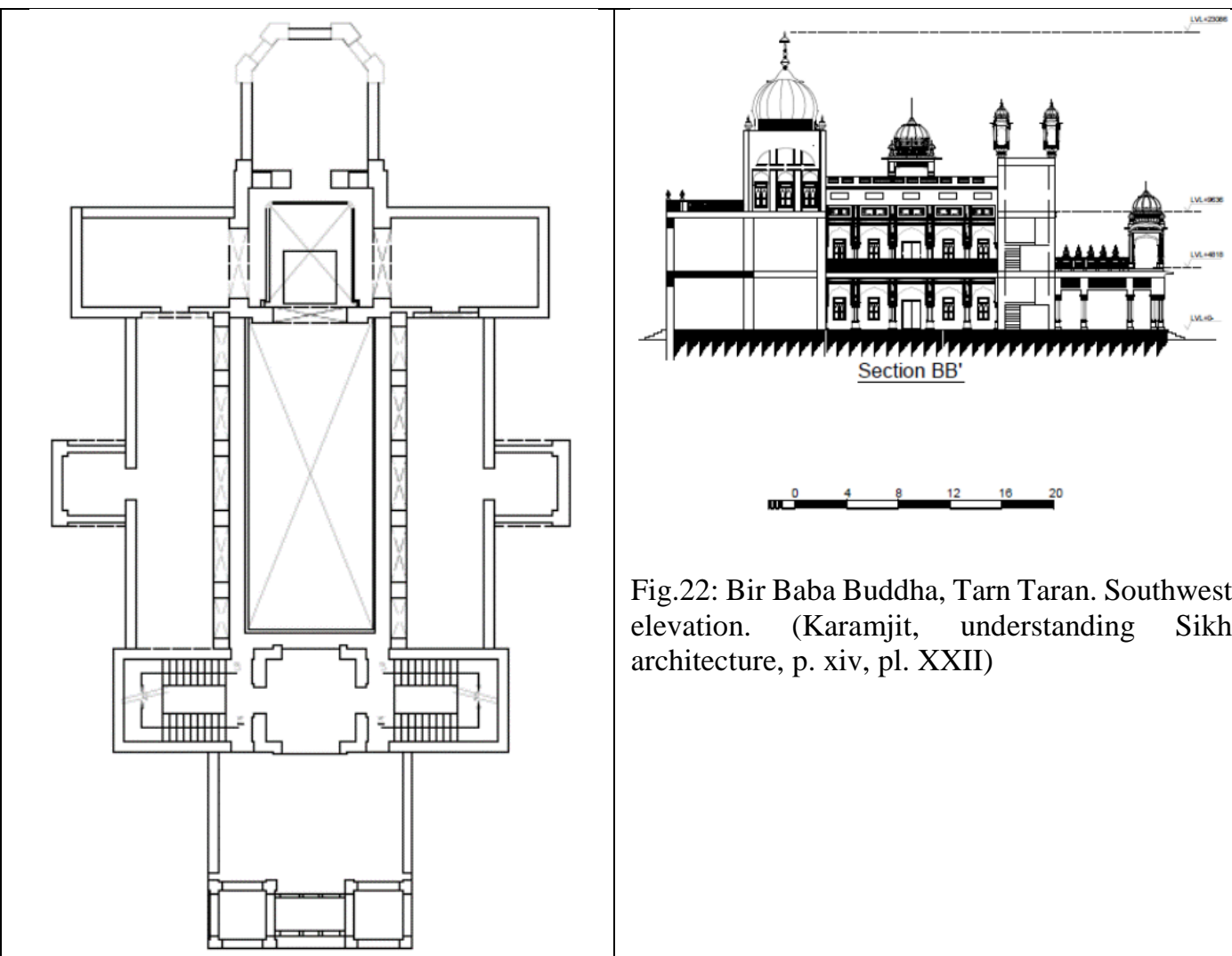

Fig. 21: Bir Baba Buddha, Tarn Taran, ground floor. (Karamjit, understanding Sikh architecture, p. xiv, pl. XXII).

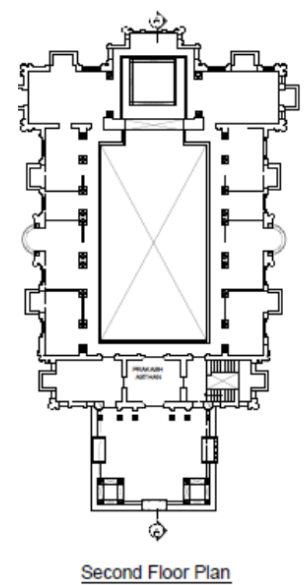

Fig.22: Bir Baba Buddha, Tarn Taran. Southwest elevation. (Karamjit, understanding Sikh architecture, p. xiv, pl. XXII)

Fig. 23: Ber Sahib, Sultanpur Lodhi, Second floor, (Karamjit, understanding Sikh architecture, p. xiv. pl. XVI ) 


\begin{tabular}{|c|c|c|c|c|}
\hline No. & Square type & Rectangular type & Polygonal type & Cruciform type \\
\hline 1 & $\begin{array}{l}\text { Holgarh Sahib at Anandpur } \\
\text { Sahib }\end{array}$ & $\begin{array}{l}\text { Bibeksar Sahib, } \\
\text { Amritsar }\end{array}$ & $\begin{array}{l}\text { Baba Atal in } \\
\text { Amritsar } \\
\text { "octagonal type" }\end{array}$ & $\begin{array}{l}\text { Nanak Jhira in } \\
\text { Bidar, Karnataka }\end{array}$ \\
\hline 2 & $\begin{array}{l}\text { Guru Ka Lahore at } \\
\text { Anandpur Sahib }\end{array}$ & $\begin{array}{l}\text { Janam Asthan } \\
\text { Patsahi Chhevin, } \\
\text { Vadali, Amritsar }\end{array}$ & $\begin{array}{l}\text { Lohgarh, } \\
\text { Anandpur Sahib } \\
\text { "octagonal type" }\end{array}$ & $\begin{array}{l}\text { Bir Baba Buddha } \\
\text { Tarn Taran }\end{array}$ \\
\hline 3 & $\begin{array}{l}\text { Hari Mandir Sahib, } \\
\text { Kartarpur }\end{array}$ & $\begin{array}{l}\text { Darbar Sahib, Dera } \\
\text { Baba Nanak }\end{array}$ & $\begin{array}{l}\text { Shaheedan } \\
\text { Sahib, Amritsar } \\
\text { "six sides" }\end{array}$ & $\begin{array}{l}\text { Ber Sahib } \\
\text { Sultanpur Lodhi }\end{array}$ \\
\hline 4 & $\begin{array}{l}\text { Tibbi Sahib, Jaito Mandi, } \\
\text { Dist Fandkot }\end{array}$ & San Sahib, Amritsar & $\begin{array}{l}\text { Harimandir } \\
\text { Sahib Amritsar } \\
\text { "six sides" }\end{array}$ & \\
\hline 5 & Gobind Gath Bathinda & $\begin{array}{l}\text { Datansar Sahib, } \\
\text { Muktsar }\end{array}$ & $\begin{array}{l}\text { Thara Sahib, } \\
\text { Amritsar } \\
\text { "Twelve sides" }\end{array}$ & \\
\hline 6 & Sahid Ganj & $\begin{array}{l}\text { Manji Sahib, } \\
\text { Alamgir }\end{array}$ & $\begin{array}{l}\text { Baba Gurditta Ji } \\
\text { Daroli, Dist, } \\
\text { Moga " oval" }\end{array}$ & \\
\hline 7 & Ramsar Amritsar & $\begin{array}{l}\text { Fatehgarh Sahib, } \\
\text { Anandpur }\end{array}$ & & \\
\hline 8 & $\begin{array}{l}\text { Chobara Sahib, Goindwal, } \\
\text { Dist Amritsar }\end{array}$ & $\begin{array}{l}\text { Keshgarh Sahib, } \\
\text { Anandpur }\end{array}$ & & \\
\hline 9 & Darbar Sahib, Tarn Taran & $\begin{array}{l}\text { Hatt Sahib, } \\
\text { Sultanpur Lodhi }\end{array}$ & & \\
\hline 10 & Baba Bir Singh, Amritsar & & & \\
\hline 11 & Anandgarh Sahib, Anandpur & & & \\
\hline 12 & Sisganj Sahib, Anandpur & & & \\
\hline 13 & Burj Sahib, Dhariwal & & & \\
\hline 14 & $\begin{array}{l}\text { Chola Sahib, Dera Baba } \\
\text { Nanak }\end{array}$ & & & \\
\hline 15 & Achal Sahib, Batala & & & \\
\hline 16 & Tibbi Sahib, Muktsar & & & \\
\hline 17 & Rakabsar Sahib Muktsar & & & \\
\hline 18 & Pipli Sahib, Amritsar & & & \\
\hline 19 & $\begin{array}{l}\text { Fatehgarh Sahib, Fatehgarh } \\
\text { Sahib }\end{array}$ & & & \\
\hline 20 & $\begin{array}{l}\text { Katalgarh Sahib, Chamkaur } \\
\text { Sahib }\end{array}$ & & & \\
\hline 21 & $\begin{array}{l}\text { Garhi Sahib, Chamkaur } \\
\text { Sahib }\end{array}$ & & & \\
\hline
\end{tabular}

Pl.5: Gurudwaras plans type dating to the $16^{\text {th }}-19^{\text {th }}$ centuries, including undated ones. 


\section{ARCHITECTURAL ELEMENTS}

Sikh architecture generally is a blend of Mughal ${ }^{1}$ and Iranian architecture. The large courtyards are empty open spaces with an elevated platform, which attracts the eye to the sanctuary of Adi Granth throne structure. The dome, the arches, the minarets and the underground cellars bear the mark of the Mughal style, whereas the plans, arches, the decorative technique and style come directly from Safavid and Qajar dynasty.

Many unites in Gurudwaras appeared before in many ideological architecture in Iran. ${ }^{2}$

\section{The Components of the Gurudwara}

Materials: brick, tiles, marble and plaster.

Tile's decorations take two forms; first the tiles which are about six inches square with a design, the second being the mosaic tiles. The manufacturing process of these mosaic tiles is only known in Persia and north India. During the $16^{\text {th }}-17^{\text {th }}$ century, it was an important industry. The material of the tile extended beyond clay; its base appears to have been composed of disintegrated sandstone ground into a powder. Under specific conditions, it forms a crude porcelain of a whitish colour, giving its transparent quality to the glaze. Each piece of the design was cut out similarly to the pieces of a jigsaw puzzle, then cemented into the required position in the design. ${ }^{3}$ Voyager Chardin describe it by saying "It is probable that these tiles were imported in bulk from Persia to India". "These tiles were called in Punjab "Kashi work", referring to the manufacturing town Kashan. In addition, they were decorating fresco and the inside of the Gurudwara.

Colours: white and gold colours on the main Gurudwaras.

Water Tank sarovar: the idea of placing a building in the middle of water is common in India, It has been done through large religious communities before Sikh. This location is not just an isolated shrine from its earthly environment. Its reflection in the water adds to its religious and artistic impacts. ${ }^{5}$ Sikh in their second doctrine transformation of political relationship started the baptism practice amrit by using sanctified sweetened water during the initiation ceremony. This ceremony was mostly done by the Sikh who has been initiated into Khalsa ${ }^{6}$ for example in Darbar Sahib, Harmandar Sahib, and Bibeksar Sahib. Therefore, they need a reservoir or a body of water.

Central sanctuary: the prayer hall which represents the heart of the shrine, is regularly located in the middle of the Gurudwara, sometimes on the last third of it. It always has a passage or a gallery around it. It is higher than the floor in the middle with the holy book Adi Granth, standing on its throne. This hall is topped by the central dome of the Gurudwara.

\footnotetext{
${ }^{1}$ It is known that Mughal architecture style is influenced by Rajput architecture style, and vice versa. This influence is clear in the massive columns, portals, interior structures, rows of three or four windows designed in the form of open split lotus. The kiosks on the parapet, the red stone, all of this connect the architecture to the Rajput one. Kumar, Critical Analysis of Jain Architecture, p. 90.

${ }^{2}$ For more information see; Gemaiey, "Ideological connotations of the inscriptions of Juma masjed of Isfahan"

${ }^{3}$ Brown, Indian architecture, 108

${ }^{4}$ Langles, Voyage du Chevalier Chardin, vol.4, 165

${ }^{5}$ Brown, Indian architecture, 114

${ }^{6}$ Singh, "Sikh architecture", vol.2, 250
} 
Circumference Parikarma: this is fundamental in Gurudwaras. Hence, Sikh cruise clockwise in the prayer hall Parkash Asthan. Some Gurudwara have two inner circumferences, like Katalgarh Sahib. The rectangular porch before the sanctum, structurally facing the sanctum with the extra hall, is used as a gathering hall.

Pavilion: The pavilion or kiosk is surmounted by a dome, lined at its base with smaller cupolas. ${ }^{1}$ There are square and octagonal kiosks.

Entrance: there are many entrances to a Gurudwara, one on each side. The main one normally faces the Adi Granth Sahib Holy (prayer hall), in the main line between the central sanctuary and the main entrance. Some entrances are memorial ones. Unlike a Hindu Mandir, Gurudwara had four doors, one in each direction, open to everyone. It aimed to show that it was open to all four castes, and to the north, south, east and west. Unlike Hindu Mandir, to enter Gurudwaras, one had to go down a few steps rather than climbing them, as G. Arjan taught his follower "No matter how lowly a person is, he must become even more humble to meet God". ${ }^{2}$ Unlike in Hindu and Buddhist temples, followers have to go up by many steps. In Iran there is a religious building have the main aspects like Gurudwara called Zur-kana. ${ }^{3}$

Towers: Gurudwaras have between two and four towers. They are square or octagonal in plan, similarly to the domes. Others don't have any, only a pavilion or a kiosk on the last floor.

Chhatris: They are elevated dome-shaped pavilions, which originate from the Rajasthan architecture where these were standard in most buildings. Chhatris was above the entrance in the Gurdwaras. Sometimes with a parapet, they typically have a rectangular plan and have curved eaves on all sides with an extended domical roof on top. Floral patterns decorate it, such as the lotus design at the base of the dome of the main Gurudwaras. Normally chhatris have three arches opening the longer sides and one on its shorter sides. In rare cases, when chhatris have five arches, small kiosks are attached on both sides. ${ }^{4}$

Domes: Different dome shapes are used, such as hemispherical, oblong, conical, and three quarters of a sphere. The latter form is the most used. The dome rises from a floral base and has an inverted lotus symbol on the top, from which the fine ornaments rise. Domes are fluted or ribbed. Some domes are covered with slabs of marble or pieces of white or coloured ceramic tiles. In addition to the large central dome there are often four others, one at each corner. There are also several solid domes embellishing the parapet. The central dome is invariably crowned by an ornate shape in brass or gilded copper. The domes are mostly built by square transfer into octagons, subsequently becoming a sixteen-sided base to a circular shape, so that the dome fits into it.

Arches: Gurudwaras use many types of arches, mostly cusped arch and its derivatives, like the three centred cusped arch, the pseudo-three centred cusped arch, the cusped drop arch, the elliptical cusped arch, the recessed cusped arch, and the plain arch.

Window with balcon Jharokha: This is a type of overhanging enclosed balcony, commonly used in Mughal and Rajasthan architectures. It juts out from the wall. It was used for aesthetics as well as for light and ventilation. A Jharokha has two or more pillars, balustrade and a cupola or gabled roof. The Jharokha is one of the most

\footnotetext{
${ }^{1}$ Singh, "Sikh architecture", vol. 2, 185

${ }^{2}$ Bigger, introduction to Sikhism, 4.

${ }^{3}$ Gemaiey, "Zūr-kha'na", vol. 5. 69-81

${ }^{4}$ Singh, "Sikh architecture", vol.2, 191-192
} 
distinctive characteristics of the façade in medieval Rajputana and Muslim architecture up to the $19^{\text {th }}$ century. ${ }^{1}$ Most Gurudwaras have no balconied windows, except for Harmandar Sahib, Darbar Sahib, Baba Atal, Keshgarh Sahib, Fatehgarh Sahib, Kangha Sahib, Anandgarh Sahib, Katalgarh Sahib, Sisganj, Akal Takht.

Parapets: there are many types of parapets; parapets with cupola, parapets with turret, parapets with kiosk, and plain parapets. Parapets with cupolas are used in most Gurudwaras, except for Pipli Sahib, Baba Bir Singh, Baba Atal, Ber Sahib, Rakabsar, Tibbi Sahib, Datansar, Janam Asthan Patsahi Chhevin, Baba Gurditta, Manji Sahib, and Thara Sahib Buddha. Some parapets did not have cupolas but were covered by a turret, such as Lohgarh, Holgarh Sahib, Thara Sahib, Anandgarh Sahib, Janam Asthan Patsahi Chhevin, Baba Gurditta, Fatehgarh Sahib, San Sahib, Bir Sahib. When a parapet is with a kiosk, it is often used as an additional unit to the cupolas or turrets. Sometimes, it is a separate unit; for example, in Burj Sahib, Bir Baba Buddha, Kandh Sahib Katalgarh sahib, and Tap Asthan Baba.

Decoration: the Gurudwaras have many motifs and figures used in the internal and the external decorations, with floral, geometrical, human, and animal patterns. These figures often are representations of Hindu mythological themes, reflecting the original spirit of the Vaishnava cult, or inscriptions from G. Granth Sahib written in gold. In that case, the Sikh scriptures did not dominate the building.

The technique used in many Gurudwaras is the mosaic combination of gold, brass, and copper with various colours of Kashani mosaic with cut glass shapes of different sizes. They also used fresco as a decorative technique. Mirrors decorate the Harmandar Sahib on the second floor, in the pavilion known as sheesh Mahal "mirror room".

\section{THE INFLUENCE OF THE ISLAMIC ARCHITECTURE}

According to Brown, "Under patronage of the Mohammadien - Mughal dynasty - the building art in northern India attained its most sumptuous form". ${ }^{2}$ The Mughal and Safavid architecture reflect their influence on the Sikh architecture even after the rise of the Sikh as an empire, by Maharaja Ranjit Singh. ${ }^{3}$ Mughals were also credited with having introduced the dual-vaulted dome in the architecture, and the dura stone-cut decorations. $^{4}$

However, Sikh architecture does not lack originality, as some Gurudwaras are uniquely located on a surface of water. ${ }^{5}$ The concept of being humble when entering the Gurudwara by descending stairs is also very specific, only partially resembling the entrance of the Zur-kāna, ${ }^{6}$ in Yazd (Iran, Pl. 9).

\footnotetext{
${ }^{1}$ Singh, "Sikh architecture", vol.2, p. 193.

${ }^{2}$ Brown, Indian architecture, 88.

${ }^{3}$ Many examples reflect the late Mughal type in civil Sikh architecture like the Samadhi of Maharaja Ranjit Singh in Lahore and Khalsa college in Amritsar. Brown, Indian architecture, 225 Kumar, Critical Analysis of Jain Architecture, 90

${ }^{4}$ Parihar, Some Aspects of Indo-Islamic Architecture, 255

${ }^{5}$ The concept of having a religious building on a body of water does not exist in Islamic architecture, especially an artificial one. In Islamic architecture it is common to build close to water or on shores, like Ortaköy Camii, officially the Büyük Mecidiye Camii in Beşiktaş, Istanbul, Turkey. It is situated on the waterside of the Ortaköy pier square, one of the most popular locations on the Bosphorus. Gemaiey, "Balyan family", pp. 101-124. In modern times, this design reappears at the mosque Hassan the Second (Casablanca), and in Malaysia at Kota Kinabalu Mosque.

${ }^{6}$ The House of strength is a religious and traditional gymnasium architecture of urban Persia, spread during the Safavid period for ideological reasons. The martyr of Imam Hussein is translated in hymns
} 


\section{Architectural Plan}

The plan is centred on a large and wide courtyard, with tall minarets of many floors at the edges of the central open space, as seen in mosques and madrassa in Iran and India before the rise of Sikhism ${ }^{1}$ (Fig. 24,25,26,27). as well as the use of double squares in the main layout of the mosques appear in the Gurudwara, the coverage of the inner square by a central dome and semi-circle domes in the corners, at the same while support the corners of the outer wall of the mosque with semi-circle towers is often seen in mausoleums and mosques in and outside India, for example the mausoleum of I'timad-ud-Duala in Agra, the mausoleum of Safa-dar-Ganj, Delhi, and the mausoleum of Islam Khan in Fatehpur Sikri. The space and perimeter of all parts is consistently observed in both Sikh and Islamic architecture, even the more precious unit in Sikh architecture, the Adi Granthi, located on the main axis of the building, such as the mihrab and the main Iwan in Islamic architecture, beside using same arches of the interior and exterior façades, with multiple bulbous domes and pavilion stands on minor pillars.

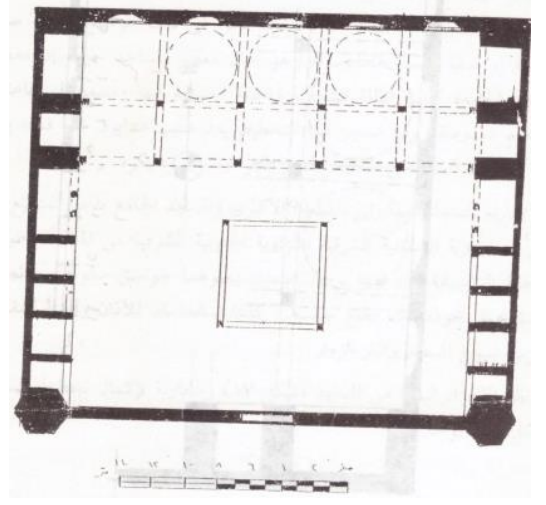

Fig.24: Humayun Shah Mosque plan, in Agra. (Ragab, al'marah alīslamīh fi Agra, India, fi el'sr al Mghawlay, p. 102, Fig.112)

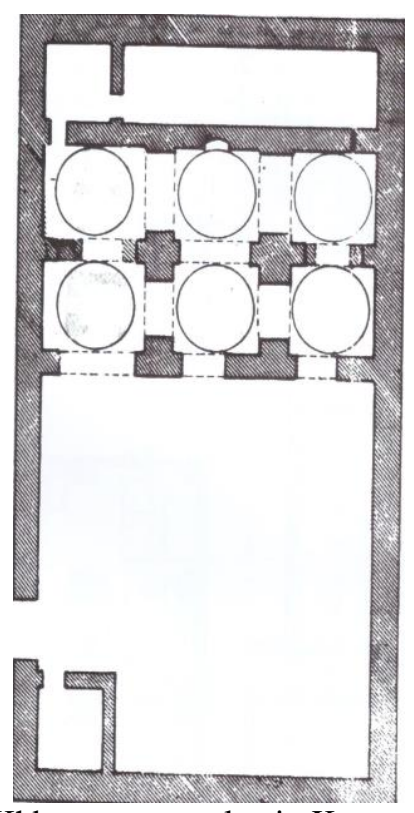

Fig.25: Khbyṣ mosque plan in Kerman. (Gemaiey, al'marah alīslamīh fi Iran, p. 54, fig.14)

and songs, similarly to what happened in the Gurudwara. To enter the building, Sikh have to bend, and to enter the Gowd we have to descend stairs. Gemaiey, "Zūr-kha'na", vol.5, 69-81

${ }^{1}$ Pop, "a survey of Persian art"; Brown, Indian architecture; Nath, Islamic architecture and culture in India. 


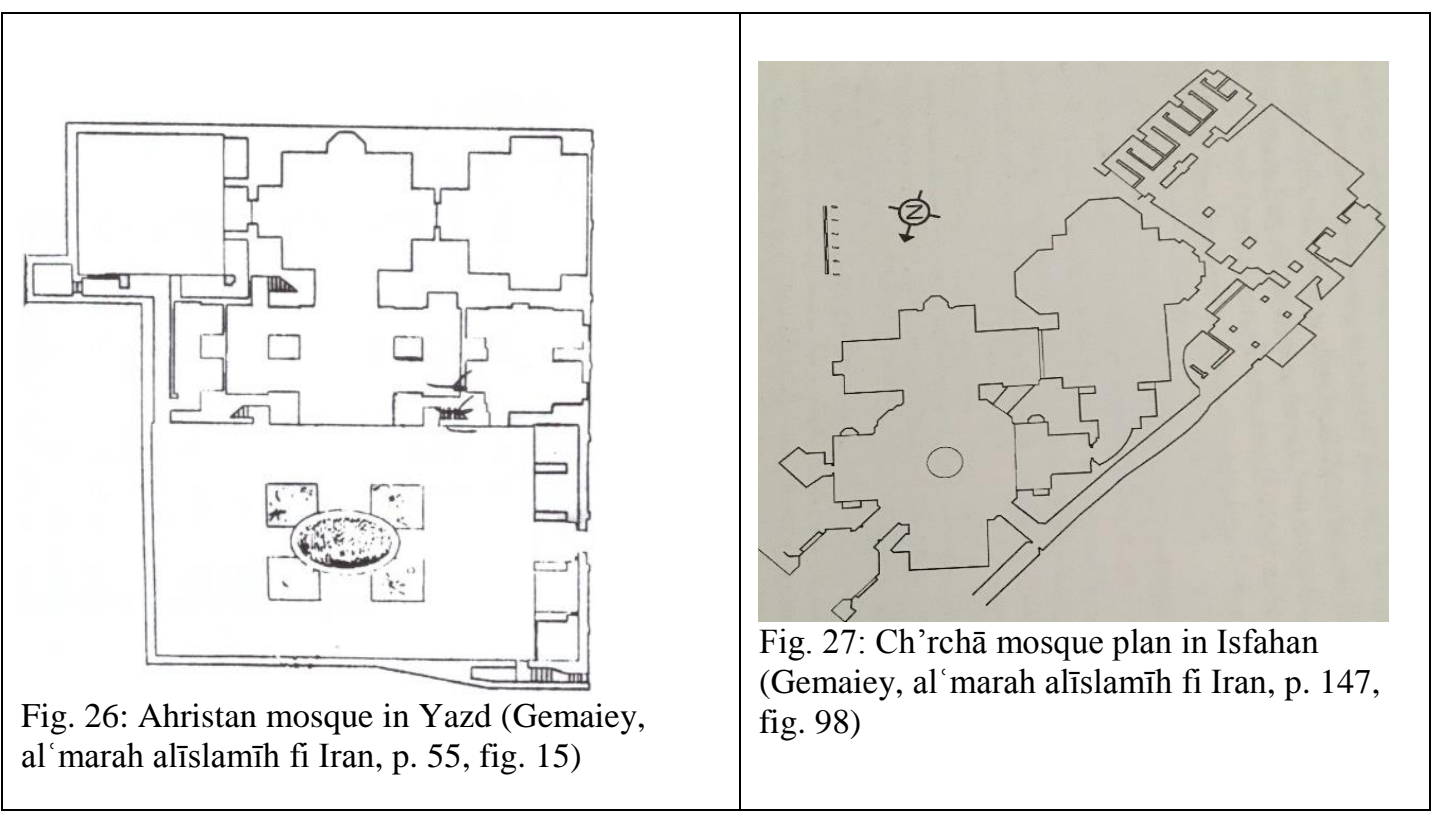

\section{Architectural Elements}

Materials: the building materials used in Gurudwaras are considered a gift of the homeland, similarly to the practice seen in Mughal architectural practices. However, Sikh also imported materials from Persia to use in their decoration like Kashani, and some technique styles, like sheesh style in some Gurudwaras.

The Colours: the colours of Sikh architecture are typically similar to the Mughal ones, even regarding the use of the red in forts of the Mughal Empire. Colours of decoration are Persian, as some appear in the Mughal architecture. Some are unique due to Safavid mosaic and fresco.

Water tank: as direct influence from the Safavid period, water tanks are found in Chehel Sotoon Palace and Hasht Behesht palace in Isfahan. Uniquely, the Gurudwara is located on the water tank, while it usually surrounds the Iranian palaces. The symbolism remains the same, referring to the reflection on the body of water ( $\mathrm{Pl} .10$, 11).

Minarets and Domes: the form of minarets used in grand space as a main plan of Sikh architecture (Pl. 6, 7), on top of using the minaret form for towers in and out the Gurudwaras. Indian Islamic domes and Indian Islamic drums appear in the roofing of the Gurudwaras, especially the Chamber of Adi Granthi (Pl. 8).

Main entrance: the main access is in the same axis, between the mihrab and main entrance, like the main entrance in the main access with Adi Granth in the prayer hall.

Chhatris: similarly to Humayun's tomb in Delhi and the Taj Mahal at Agra, chhatris have been used extensively in Rajput architecture as well. It may be one of the most popular units of Mughal architecture in the Rajput.

Balconied windows: the balconied windows, such as those seen in the interior facade of Delhi Gate of the Agra Fort, initially seen in the Mughal structures, they are seen in the architecture of the Rajput.

Decoration: mosaic Jaratkari resembles the Mughal technique which was used for the decoration of the Taj Mahal at Agra. The decoration of the Harmandar Sahib has an edge over the mosaic of the Taj Mahal thanks to its addition of human and animal 
figures on top of the usual floral designs, as seen in the Taj. Many of the artists who worked in the Harmandar were Muslim. Maharaja ordered Muslim painters who were experts in this art to decorate the Gurudwara. The decoration work with fresco paintings and naqqashi work, was done by these Muslim painters belonging to west Punjab in the early $19^{\text {th }}$ century. ${ }^{1}$ Muslim artists of Lahore and Pahari artists thus worked in Mughal style. Decorative techniques, such as colour schemes, landscape surrounding the figures, portraits, use of halo around the principal figure, use of gold in the border, were inspired from the Mughal period. Because Lahore used to be a provincial capital of the Mughal Empire, artists' studios existed there since Humayun when Persian masters of calligraphy and painting came to Lahore and settled down. Mirrors in decoration is an Iranian influence on Sikh architecture, even they use the same name, material, technique of mirrors decoration. Sheesh style decorated fabric, tablecloth, garments and walls. The first use of Sheesh in Iran dates to 1557, at the time of Tahmasp Shah, in Qazvin, the Safavid capital. ${ }^{2}$ It was then used by Mumtaz Mahal in her mausoleum in Agra.



\footnotetext{
${ }^{1}$ Singh, "Khalsa heritage of Sikh art in Gurudwaras", 100-103.

${ }^{2}$ Shkolna, "Mirror interiors in Iranian architecture", issue 15, 111.
} 


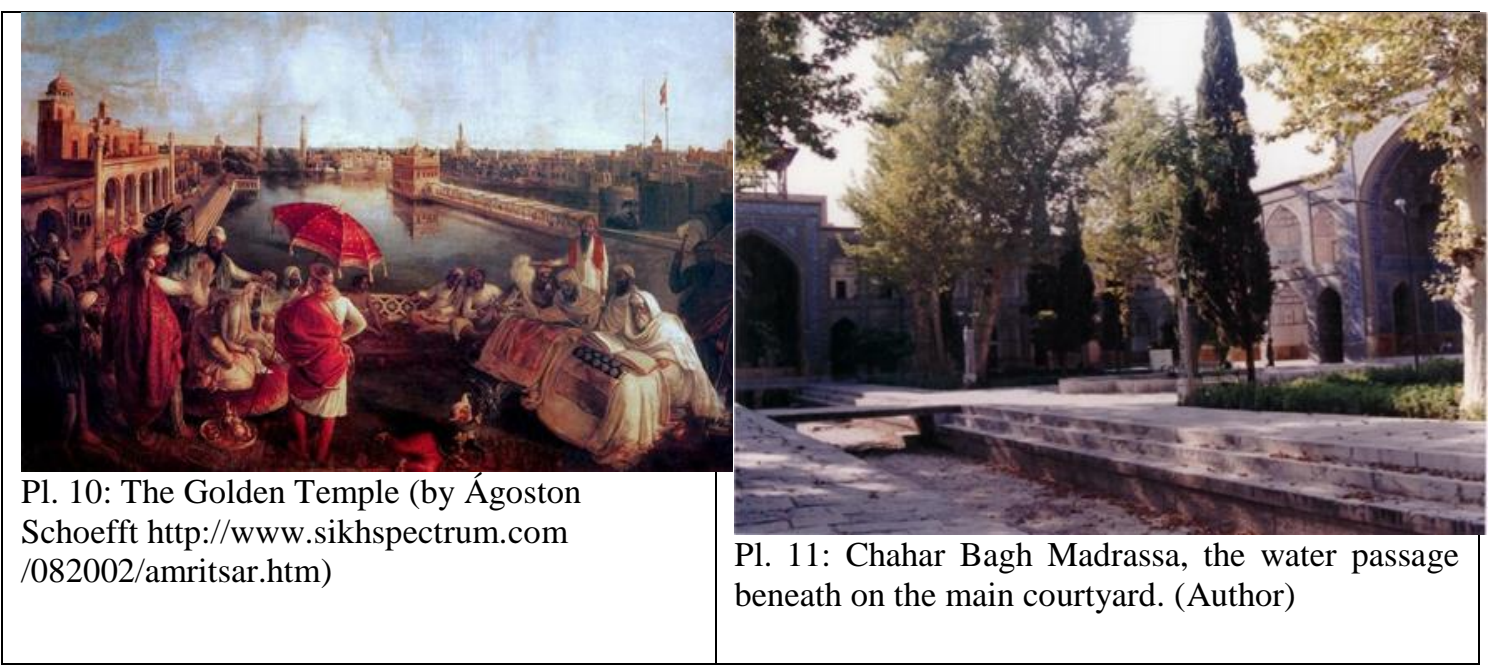

\section{CONCLUSIONS AND RESULTS}

Addressing the design of Sikh Gurudwaras shows the influence of Islamic architecture, especially the Iranian and the Mughal Indian ones. This is due, in parts, to historical and geographical contacts between the Sikh and the Muslim cultures in the same subcontinent. Considering the difficulties in filtering the different architectural patterns from Hindu, Buddhist, Jain, and Muslim architecture, it is clear that Sikh architecture kept an original edge, by using new elements never seen before in Muslim or Hindu structures. Meanwhile, the Sikh architecture still requires further research to show the different parties' influences.

Sikh's design and components of the Gurudwaras is a combination of Mughal and Safavid Empire. They adopted also from Hindu architecture the distribution of the units, so, some of Sikh architectural units originate from the Hindu architecture, like the sanctuary or the prayer hall that adapt Adi Granth, which Sikh intended to walk around it clockwise, as it is similarly done in Hindu temple. The sanctuary in Hindu temple was seen as the residence of a specific God in which walks around the inner sanctuary were completed clockwise. Although Gurudwaras are more spacious than Hindu temple.

The influence of Iranian architecture and the Mughal one appear in many aspect such as, the first Gurudwara built during the Sikh period known as Harmandar Sahib was built with four entrances in the four façades found in Mughal shrines, such as Char Taq, in Central Asia. The concept of an open entrance in the middle of every façade is known in mosques all over the world. The main entrance always is on the axis of the central sanctuary, as seen in mosques. Many feature of Zur-kāna are similar with Gurudwara like the same use of hymns, songs, and instruments. Gurudwaras have a common kitchen and dining room called Langar, like in the complex in the Safavid region especially in Hussinyat. Gurudwaras are recognisable by the yellow or blue flag (nishan sahib), as seen in ideological architecture in Iran (Hussaini and Zur-kana).

One of the reasons of the similarity of Islamic architecture and Sikh architecture is that many architects and artists of the Gurudwaras were Muslims.

Never forget to refer to the uniqueness of Sikh architecture in some unites, which didn't appear before in Hindu or Islamic architecture, like using the sheet of water to build upon it. Islamic architecture had not designed mosques or madrassas built on a surface of water. This is a unique characteristic of Sikh architecture. It now influences on

- 135 - $\mid$ DOI: $10.21608 /$ shedet.2021.207836 
Islamic architecture from Sikh in Malaysia and some countries in Far East. Beside Gurudwaras are not oriented in any specific direction unlike Hindu temples and mosques, and have no required architectural pattern, except for the installation of the Guru Granth Sahib in a building under a canopy on a platform higher than the floor.

Most Gurudwaras have the same type as the Harimandir Amritsar, the holiest sanctuary of the Sikhs located in the walled city of Lahore.

\section{ACKNOWLEDGMENT}

I want to express my appreciation to all authors who continuously contribute to the field of Sikh architecture. Many have shared their articles and thesis, giving easy access to their files. This enabled this research thanks to the plans and sections of the Sikh architecture. Special mention to Karamjit Singh the authors of Understanding Sikh Architecture through the Sikh Shrines in East Punjab (2012). 


\section{BIBLIOGRAPHY}

1- Banerjee, A. C., Guru Nanak to Guru Gobind Singh, Kolkata, 1978.

2- Bhui, D.S., The Golden Temple: A synthesis of Styles, in Singh Parm Baksheesh, Publication Bureau, Punjabi University, Patiala, 1999.

3- Bigger, S., "Introduction to Sikhism", teaching materials for MA in the religious education, unpublished, India, 2004.

4- Brekke, T., "Sikh Tradition", in Cambridge M. Reichberg, and Syse (ed.), Religion, War and Ethics, a sourcebook of textual tradition, London, (Cambridge press. 2014), 672-700.

5- Brown, P., Indian architecture - Islamic period, $7^{\text {th }}$ edition, Bombay, 1981.

6- Crim (Keith), Abingdon Dictionary of Living Religions, London, 1981.

7- Dhillon, G., "Gurdarshan Singh. Singh Sabha Movement - A Revival”, in Institute of Sikh Studies Jasbir Singh Mann (ed.), Advanced studies in Sikhism, (Chandigarh, 1989), 234-262.

8- Gemaiey, G., "Uwsrat Balyan wa dawrwha alfnī wa alm 'marī îla al 'imara al dīnīa; fi al'ṣr al 'thumanay fi Istanbul khilal alqrn 13/19" (Balyan family and its art and architecture role in Ottoman religious architecture in Istanbul during 13/19 century), in Garay/ (ed.), alhrf wa almhrat wa alhīah almhnīh fi al alm almtwsțay mn khilal almșadr alathrīh, Tunis, (2010), alm 'hd al'alay lmhin altawrath 2014, 101-124

9- - . "Hussaini, the influence of the sectarian doctrine on the architecture of the Shi' a mosques in Iran", Journal of humanities and social science 4, (2014), India, 100-118.

10- - "Ideological connotations of the inscriptions of Juma masjed of Isfahan", Mediterranean Archaeology and Archaeometry 14, Greece, (2014) , 273-289

11- —, al marah alīslamīh fi Iran: Masagd- Madarīs- Hawsaynyat, (Islamic architecture in Iran: Mosques, madrassa, Hussaini) Anglo Egyptian, 2014.

12__. "Zur-knhāna”, Journal of research and archeological studies 5 (2019), Minia, 69-81.

13- Grewal, J. S., Social and Cultural History of the Punjab, Manohar Publishers, 2004.

14- Hasan, J (ed.), Mapping the Mughal city of Agra: proceedings of the Indian history congress, India 1990. Vol. 51, Indian history congress, 241-245.

15- Jutla, R, S., The visual and spatial structure in Mughal urban design: the $16^{\text {th }}$ century city of Fatehpur Sikri, India, manuscript PhD dissertation, Virginia, 1995.

16- Kalsi, S, S), "Sacred Symbols in British Sikhism”, Internet Journal of Religion, Agra 1997. 3 vol, Agra, 111-117

17- Karamjit, S, Understanding Sikh Architecture through the Sikh Shrines in East Punjab, manuscript PhD thesis, India, 2012.

- 137 - $\mid$ DOI: 10.21608/shedet.2021.207836 
18- Kapoor, S.S., "The Rise of the Sikh Empire, The Times of Maharaja Ranjit Singh 17991839", in S.S. Sodhi, J. S. Mann (ed.), The Source Book On Sikhism, (Halifax, NS. 2000) Canada, 466-476.

19- Khushwant, L., A History of the Sikhs, vol. I, Delhi, 2004.

20-Kumar, R., Critical Analysis of Jain Architecture in Bihar Region and its Influence on Regional Architecture, manuscript PhD. Thesis, Department of architecture, National institute of technology Patna, Bihar, 2018.

21- Langles, M., Voyage du Chevalier Chardin, vol. 4, Paris, 1811.

22- Loehlin, C.H., The Sikhs and Their Scripture. Lucknow Publishing House, India, 1958.

23- Nath, R., History of Mughal Architecture: The Age of Architectural Aestheticism, Shah Jehan, 1628-1658 A.D., Vol. 4, Part 1, Abhinav, New Delhi, 2006.

24- _ ., Islamic architecture and culture in India, B.R. Publishing Corporation, India, 1982.

25- Parihar, S., Some Aspects of Indo-Islamic Architecture, New Delhi, 1999.

26-Pop, A., A survey of Persian art, Oxford University Press, London, 1938-1939.

27- Ragab, A., al 'marah alīslamīh fi Agra, India, fi el'sr al Mghawlay 923-1275/1526-1857, (Islamic architecture in Agra, India, at the time of Mughal 923-1275/1526-1857), PhD thesis, Cairo University, 1996.

28- Shaw, E., Sikhism, overview of world religions, part of Philter religion, division of religion and philosophy, University of Cumbira, England, 1996

29- Shkolna, O., "Mirror interiors in Iranian architecture of the 19th-21st centuries, Artistic Culture study", Topical issues 15 (2019) Russia, 110-115.

30- Singh, D., "Khalsa heritage of Sikh art in Gurudwaras", Abstracts of Sikh Studies, (2003) India, 100-103.

31- Singh, G., "Sikh architecture" in Harbans Singh (ed.) Encyclopedia of Sikhism, Punjabi University (1998), Vol. 4, Patiala, 131-133.

32-Singh, P., Aotearoa Sikh architecture, a place for worship, manuscript MA. Thesis, Unitec of technology, 2013

33-Steinbach, C., The Punjab; a Brief Account the Country of the Sikhs, Second Edition, London, 1846. 